\title{
How Big Is the Debt Overhang Problem?
}

\author{
Nathalie Moyen ${ }^{\dagger}$ \\ Leeds School of Business, University of Colorado, Boulder, CO 80309-0419, USA
}

\begin{abstract}
I re-examine the debt overhang problem where the flexible investment level, rather than the irreversible decision whether or not to operate, is used to measure the underinvestment caused by debt financing. I measure a large overhang cost with long-term debt or short-term debt. As is standard, underinvestment with long-term debt is more severe when investment opportunities are poor and is mitigated as opportunities improve. In contrast, underinvestment with short-term debt remains significant even when investment opportunities are good. Firms lever up as opportunities improve to take advantage of tax shields, so that equity claimants still face the incentive to underinvest.
\end{abstract}

JEL classification: G31; G32

Keywords: Agency problems; Debt overhang; Dynamic capital structure; Underinvestment

\section{Introduction}

How big is the debt overhang problem? To answer this question, I examine firms' investment and financing decisions in a dynamic stochastic framework with an interest tax deduction benefit and

\footnotetext{
${ }^{\dagger}$ Tel.: 303735 4931; fax: 3034925962.

Email address: moyen@colorado.edu (N. Moyen).
} 
a deadweight default cost of debt. Using this framework, I quantify Myers's (1977) debt overhang problem, according to which equity claimants invest less when the proceeds of that investment are likely to accrue to debt claimants upon default. The qualitative result is well-known: the equityvalue-maximizing investment level is lower than the level that maximizes the value to all claimants. The underinvestment is costly to the firm.

The existing literature, including Mauer and Ott (2000), Mello and Parsons (1992), and Parrino and Weisbach (1999), already provides debt overhang cost estimates. Their estimates quantify the overhang problem to no more than 1.54 percent of firm value. These studies however describe the investment decision either as an exogenous rule or as a choice whether or not to operate/expand.

I contribute to this literature by allowing the firm to choose its optimal investment level each period. I characterize the magnitude of the underinvestment rather than the distortion in investment timing. I also consider two types of capital structure. Following the existing literature, the first type of capital structure assumes a fixed coupon rate - long-term debt. The second type allows for a time-varying coupon rate - short-term debt. To quantify equity claimants' underinvestment, I examine two benchmarks. The first benchmark consists of the unlevered firm, where investment does not depend on financing. The second benchmark consists of the total-value-maximizing firm, where investment and financing are jointly determined. The two benchmarks differ by the tax benefit and default cost. Only the total-value-maximizing firm takes into account the probability of losing the tax benefit and paying the deadweight cost upon default. The total-value-maximizing firm is therefore the appropriate benchmark to measure debt overhang. The unlevered firm nevertheless provides an interesting measure of the underinvestment. Finally, the income shock represents the underlying investment opportunities facing the firm in my model. Because the income shock changes over time, I am able to quantify the debt overhang problem throughout the various shocks.

Using the unlevered firm benchmark, the equity claimants' underinvestment generates a value 
loss from operations that is similar to that reported in the literature. With long-term debt, the value loss from operations represents 0.49 percent of the unlevered firm value. The loss is slightly smaller than in Mello and Parsons. Mello and Parsons examine a mine's decision whether or not to operate in a real options framework and measure the underinvestment cost to 0.8 percent of the unlevered firm value. When equity claimants can vary their investment level through time, they underinvest only in the worst income shocks, which explains the smaller value loss from operations.

With short-term debt, the value loss from operations remains about the same, at 0.46 percent of the unlevered firm value. Short-term debt however redistributes the value loss from operations across income shocks, compared to the case with long-term debt. The equity-value-maximizing firm with short-term debt decreases leverage in bad income shocks, reducing the default probability and underinvestment compared to the case with long-term debt. However, the firm increases leverage in better income shocks to take advantage of the tax benefit, raising the default probability and underinvestment. The value loss from operations is in part shifted from bad income shocks to better shocks.

Using the total-value-maximizing firm benchmark, the equity claimants' underinvestment generates larger losses. In contrast to the unlevered firm, the total-value-maximizing firm takes into account the interaction between its investment and financing decisions. While the capital investment level chosen by the unlevered firm only responds to the marginal product of capital, the capital investment level of the total-value-maximizing firm is also sensitive to the default probability and its deadweight costs. The firm invests more than the unlevered firm to reduce its probability of default. More investment, up to the point of not defaulting this period, generates more revenues next period, thereby reducing the probability of defaulting and the probability of losing the tax benefit and paying the deadweight cost upon default. This significantly raises the benchmark from which the underinvestment is measured. 
With long-term debt, the value loss from operations represents 2.61 percent of the totalmaximizing firm value. The debt overhang cost, measured by the loss in firm value which includes the loss of tax shield, adds up to 4.70 percent of the total-maximizing firm value. The debt overhang cost with long-term debt is larger than reported in the literature. Mauer and Ott examine a firm's decision whether or not to expand operations using a real options framework and measure the debt overhang cost to no more than 1.54 percent of the equity-maximizing firm value. Titman and Tsyplakov (2003) report that the equity-maximizing firm value differs from the total-maximizing firm value by 2.1 percent of the untaxed, unlevered firm value with long-term debt. The different degrees of investment flexibility explain the different results. Mauer and Ott model an irreversible decision whether or not to expand, Titman and Tsyplakov constrain investments into the capital stock to be irreversible, while I allow for full investment flexibility. With more flexibility to manage its default probability, the total-value-maximizing firm is able to accumulate a larger tax shield and control its probability of default by investing more in bad income shocks. The total-valuemaximizing firm that benchmarks debt overhang is greatly affected by investment flexibility. More investment flexibility magnifies the debt overhang cost.

With short-term debt, the value loss from operations represents 4.98 percent of the totalmaximizing firm value and the debt overhang cost adds up to 5.12 percent. The debt overhang cost with short-term debt is larger than reported in the literature. Titman and Tsyplakov quantify the overhang cost with short-term debt at 5.9 percent of the unlevered, untaxed firm value, but their short-term debt has an average maturity of 20 years. With a maturity of five years, their debt overhang cost decreases to 2.2 percent. Reducing the debt maturity from 20 to five years reduces the overhang due to the long maturity debt structure. My larger debt overhang cost again arises because I allow for full investment flexibility.

The results in my paper complement the existing literature. The paper most closely related to 
mine is the contemporaneous work of Titman and Tsyplakov. Titman and Tsyplakov and my study quantify the debt overhang problem in a dynamic framework. Together, the papers clearly show that overhang increases with investment flexibility and remains a problem with short-term debt. My study draws attention to the overhang under various income shocks. Overhang with long-term debt is more important in worse income shocks, and is surpassed by overhang with short-term debt in good shocks.

Mauer and Ott and Mello and Parsons examine the operating distortion cost of debt in a real options framework. Following Brennan and Schwartz (1984), the binary decision whether or not to operate depends on an underlying price process related to the firm's revenues. Mello and Parsons examine the option whether or not to operate, while Mauer and Ott focus on the decision whether or not to expand operations. In addition, Mauer and Ott find that the agency cost can be lowered by partially financing the expansion with a debt issue.

Parrino and Weisbach conduct Monte Carlo experiments to quantify the debt overhang problem, along with the asset substitution problem. ${ }^{1}$ They quantify the wealth transfer from equity claimants to debt claimants arising from the adoption of low-risk positive-net-present-value projects, and the converse transfer arising from the adoption of high-risk negative-net-present-value projects. The Monte Carlo experiments suggest that these agency costs are unlikely to be important. In contrast to the other papers in this literature, investment and debt decisions are described by exogenous rules.

Hennessy (2004) demonstrates that agency costs are empirically relevant. Hennessy compares an equity-value-maximizing firm with debt in place to an unlevered firm. The theoretical analysis emphasizes that overhang distorts not only the level of investment but also its composition, with

\footnotetext{
${ }^{1}$ Studies that quantify the asset substitution problem include Leland (1998) and Ericsson (2000). In addition, Morellec (2004) and Parrino, Poteshman, and Weisbach (2005) quantify another agency conflict, the conflict between equity claimants and their managers.
} 
firms underinvesting more severely in longer-lived assets. Hennessy also develops an empirical proxy for Tobin's marginal $q$, equal to average $Q$ minus a debt overhang correction term (the ratio of bondholders' recovery in default over capital). This proxy along with other assumptions, notably assumptions on the adjustment cost function, yields a linear investment regression specification. The specification is estimated including cash flow terms and using the GMM procedure of Erickson and Whited that accounts for possible errors in measuring average $Q$. The investment-cash flow sensitivity estimation results reveal that the debt overhang correction term behaves as expected: it reduces investment.

Consistent with Hennessy, my debt overhang estimates are significant. However, I argue that debt overhang needs to be benchmarked against the total-value-maximizing firm, which accounts for the interaction between investment and financing decisions. I focus on quantifying the loss in firm value from the underinvestment within a calibrated framework of dynamic investment and financing decisions. My analysis shows that, contrary to conventional wisdom, the overhang problem is not mitigated by shortening the debt maturity. As expected, the firm with short-term debt reduces its leverage in worse income shocks. Short-term debt overhang is therefore smaller than longterm debt overhang in worse income shocks. However, the firm levers up in better shocks to take advantage of tax shields. The default probability, and consequently the overhang problem, remain present as income shocks improve. Short-term debt overhang surpasses long-term debt overhang in better income shocks. Averaging over all shocks, the overhang problem is just as important with short-term debt as with long-term debt.

More generally, this paper contributes to the literature on investment and financing decisions that began with Modigliani and Miller's (1958) demonstration that a firm's investment decision is independent of its financing decisions. Many studies of a firm's recapitalization decision take the 
investment decision as given. ${ }^{2}$ In contrast, this paper emphasizes precisely the interaction between investment and financing decisions. ${ }^{3}$ Investment interacts with financing through the traditional debt financing frictions - a tax benefit and a default cost - in a framework that is dynamic, allows for recapitalizations through time, and imposes fair pricing.

The next section describes the different models used to measure the debt overhang problem. Section 3 presents the calibration necessary to solve the models. Section 4 quantifies the debt overhang cost. The last section concludes.

\section{The Models}

If equity claimants could commit to maximizing their value subject to fairly pricing any debt issue, they would invest in all positive net present value projects. To be clear, maximizing the equity value subject to fairly pricing the debt is equivalent to maximizing the total firm value. Under totalvalue-maximization, equity claimants would occasionally invest in projects that trigger default, where investment proceeds accrue to debt claimants.

Myers recognized that equity claimants cannot commit to maximizing the total firm value. In reality, once the debt is issued, they have the incentive to disregard the debt value and maximize their own value. Maximizing the equity value without regard to the debt already in place is not equivalent to maximizing the equity value subject to fairly pricing the debt. Equity claimants thus invest in projects that are less likely to trigger default. In turn, debt claimants rationally anticipate equity claimants' underinvestment and do not lend as much funds. The resulting firm value is lower

\footnotetext{
${ }^{2}$ Dynamic recapitalization studies include Fischer, Heinkel, and Zechner (1989); Kane, Marcus, and McDonald (1984, 1985); and Wiggins (1990).

${ }^{3}$ Other papers examining the interaction between investment and financing decisions include Bernanke and Gertler (1989, 1990); Brennan and Schwartz (1978); Calomiris and Hubbard (1990); Dammon and Senbet (1988); Décamps and Faure-Grimaud (2002); Dotan and Ravid (1985); Faig and Shum (1999); Froot, Scharfstein, and Stein (1993); Leland (1994); Leland and Toft (1996); Mayer (1986); Mella-Barral and Perraudin (1997); and Myers and Majluf (1984), among others. Most of these papers are either developed within a static framework, do not allow for changes in the debt level through time, or do not solve for endogenous claims prices.
} 
than under total-value-maximization.

I measure debt overhang as the value lost when a levered firm chooses investment to maximize its equity value rather than its total value, where each firm's total-value-maximizing leverage trades off a tax benefit of debt against a default cost of debt. ${ }^{4}$ I also measure the difference in firm values between a levered equity-maximizing firm and an unlevered firm, accounting for the tax benefit and default cost of the levered firm.

The cost of the debt overhang problem is measured first under the assumption that the firm's capital structure consists of a fixed coupon rate - long-term debt. This cost is then measured assuming that the firm's capital structure allows for a time-varying coupon rate - short-term debt. The two extreme debt structures provide information on how the overhang problem varies with flexibility in the capital structure.

Five different models are needed to compute the measures of debt overhang. The first model does not include debt financing, and represents an unlevered firm. The next two models include long-term debt, and represent a total-value-maximizing firm and an equity-value-maximizing firm. The last two models include short-term debt, and also represent a total-value-maximizing firm and an equity-value-maximizing firm. These five dynamic stochastic infinite-horizon models are presented below.

\subsection{No Debt}

\subsubsection{Unlevered Firm}

Without financing frictions such as a tax benefit and a default cost, the capital structure becomes irrelevant to the firm value. Without loss of generality, I focus on the specific case of the unlevered firm. Because the unlevered firm value depends only on investment and production activities, it

\footnotetext{
${ }^{4}$ Because I focus on the debt overhang problem, I do not model the additional agency problem between managers and equity claimants.
} 
provides a benchmark for measuring overhang that is free of financing concerns.

The firm produces income before depreciation

$$
f\left(K_{t} ; \theta_{t}\right)=\theta_{t} K_{t}^{\alpha}-F
$$

where the underlying investment opportunities are represented by an income shock $\theta_{t}$ and the capital stock is denoted by $K_{t}$. The firm's income before depreciation exhibits decreasing returns to scale when $0<\alpha<1$. To avoid modeling the labor decision, labor (and other) expenses are represented by a fixed cost $F$.

This period's depreciated capital stock and investment constitute next period's capital stock. The capital accumulation is thus represented as

$$
K_{t+1}=(1-\delta) K_{t}+I_{t},
$$

where $\delta$ is the depreciation rate and $I_{t}$ is investment. ${ }^{5}$ The firm is allowed to sell some assets, so that investment can be negative. ${ }^{6}$

The income shock follows a first-order autoregressive process with persistence $\rho$ and volatility $\sigma$

$$
\ln \theta_{t+1}=\rho \ln \theta_{t}+\sigma \epsilon_{t+1},
$$

where $\epsilon_{t} \sim$ iid $N(0,1)$.

The firm maximizes its total value by choosing how much to invest $I_{t}$, after observing the beginning-of-the-period value for the income shock $\theta_{t}$ and last period's choice of capital stock $K_{t}$. The total firm value $J$ consists of the after-tax income and depreciation tax shield net of the

\footnotetext{
${ }^{5}$ The depreciation tax shield rate is assumed to be equal to the true economic depreciation rate of the capital stock.

${ }^{6}$ There is no stock of cash in the model. The use of precautionary cash balances is ruled out without loss of generality because the firm can effectively manage its probability of default by buying and selling its capital stock.
} 
investment plus the expected discounted firm value next period. The Bellman equation is

$$
J^{U}\left(K_{t} ; \theta_{t}\right)=\max _{\left\{I_{t}\right\}}(1-\tau) f\left(K_{t} ; \theta_{t}\right)+\tau \delta K_{t}-I_{t}+\frac{1}{1+r} \mathrm{E}_{t}\left[J^{U}\left(K_{t+1} ; \theta_{t+1}\right)\right]
$$

where the superscript ${ }^{U}$ indicates a functional form specific to the case of the unlevered firm, $\tau$ is the firm's tax rate, $r$ is the discount rate, and $\mathrm{E}_{t}$ is the conditional expectation at period $t$.

The unlevered firm's investment decision is characterized by

$$
\frac{1}{1+r} \mathrm{E}_{t}\left[(1-\tau) \theta_{t+1} \alpha K_{t+1}^{\alpha-1}+(1-(1-\tau) \delta)\right]=1
$$

Equation (5) states that the firm invests up to the point where the cost of one unit of asset equals next period's expected discounted marginal product of capital. The marginal product includes the marginal after-tax income and the asset resale price.

The unlevered firm's decision may be explicitly written as

$$
K_{t+1}=\left(\frac{(1-\tau) \alpha \mathrm{E}_{t}\left[\theta_{t+1}\right]}{r+(1-\tau) \delta}\right)^{\frac{1}{1-\alpha}}
$$

where the optimal capital stock level $K_{t+1}$ increases monotonically with the income shock.

\subsection{Long-term Debt}

\subsubsection{Total-value-maximizing Firm}

In this model, the firm maximizes the value of its equity, subject to the constraint that any debt issue is fairly priced. All claimants, debt and equity, are risk neutral. ${ }^{7}$ The equity value $V$ is

$$
V_{t}=\max \left\{0, D_{t}+\frac{1}{1+r} \mathrm{E}_{t}\left[V_{t+1}\right]\right\}
$$

\footnotetext{
${ }^{7}$ Consistent with the existing debt overhang literature, the model does not specify risk averse preferences. Accounting for a risk premium is admittedly relevant when pricing risky payoffs. Correctly modeling the risk premium would involve modeling the consumption problems of debt and equity claimants, which would greatly add to the dimensionality of the debt overhang analysis. Instead, the analysis should be viewed as a partial equilibrium exercise to quantify the immediate effect of firms' deviation from total-value-maximization.
} 
where the dividend is the residual of the firm's sources and uses of funds

$$
D_{t}^{L}=(1-\tau) f\left(K_{t} ; \theta_{t}\right)+\tau \delta K_{t}-I_{t}-(1-\tau) c
$$

the superscript ${ }^{L}$ indicates a functional form specific to the case with long-term debt, and $c$ is the coupon chosen ex ante to maximize total firm value.

Equation (7) shows that the equity value is the sum of the expected discounted stream of dividends $D$. Equation (7) also shows that equity claimants are protected by limited liability. Equity claimants default whenever $D_{t}+\frac{1}{1+r} \mathrm{E}_{t}\left[V_{t+1}\right] \leq 0$. The firm may ask its equity claimants to contribute additional funds $\left(D_{t}<0\right)$, but it is sometimes not optimal for them to do so. In the case where the equity issue is not justified by the expected discounted future equity value $\left(D_{t}+\frac{1}{1+r} \mathrm{E}_{t}\left[V_{t+1}\right] \leq 0\right)$, equity claimants exercise their option of not contributing additional funds to the firm and trigger default instead.

Because the income shock $\theta$ is persistent, the firm can anticipate the income shock it will face next period and chooses its dividend and investment policies accordingly. The firm however cannot perfectly anticipate the income shock it will face next period. Default occurs when next period's income shock $\theta_{t+1}$ turns out to be much lower than expected such that the equity claim becomes worthless. $^{8}$

The income shock at which equity claimants trigger default on their long-term debt obligation $\bar{\theta}^{L}\left(K_{t}, c\right)$ is defined by $V_{t}=D_{t}+\frac{1}{1+r} \mathrm{E}_{t}\left[V_{t+1}\right]=0$. Substituting equations (1), (2), and (8) in this

\footnotetext{
${ }^{8}$ In a continuous-time framework, it would always be optimal for the firm to reset its policies locally near the boundary where the firm cannot pay its coupon. For example, the firm could move away from the boundary by decreasing its short-term debt payment or selling some assets. In the discrete-time framework, the firm cannot locally reset its policies so that default sometimes occurs. In accord with the existing debt overhang literature, I also do not allow for renegotiation between equity and debt claimants. With renegotiation to avoid default and its associated costs, the debt overhang problem would be mitigated. In fact, I do not discuss the optimal design of the debt contract, but take as given the typical corporate debt contract of coupon payments when equity claimants do not default and the net residual value upon default.
} 
expression, the default point is implicitly defined by

$$
(1-\tau) \bar{\theta}^{L}\left(K_{t}, c\right) K_{t}^{\alpha}+(1-(1-\tau) \delta) K_{t}-K_{t+1}-(1-\tau) c+\frac{1}{1+r} \mathrm{E}_{t}\left[V_{t+1} \mid \theta_{t}=\bar{\theta}^{L}\left(K_{t}, c\right)\right]=0
$$

Because $\epsilon_{t}$ is normally distributed, the income shock $\theta_{t}$ follows a log-normal distribution. Hence, the probability of default is represented by $\Phi\left[\bar{\theta}^{L}\left(K_{t}, c\right)\right]$, where $\Phi[\cdot]$ is the log-normal cumulative distribution function.

The long-term debt value is constructed as the sum of all expected discounted future coupon payments $c$ if equity claimants do not default or the residual value $R$ net of a deadweight default cost $X$ if equity claimants default:

$$
\begin{gathered}
L_{t}=c 1_{\left(V_{t}>0\right)}+\frac{1}{1+r} \mathrm{E}_{t}\left[c 1_{\left(V_{t+1}>0\right)} 1_{\left(V_{t}>0\right)}\right]+\cdots \\
+\left(R_{t}^{L}-X\right)\left(1-1_{\left(V_{t}>0\right)}\right)+\frac{1}{1+r} \mathrm{E}_{t}\left[\left(R_{t+1}^{L}-X\right)\left(1-1_{\left(V_{t+1}>0\right)}\right) 1_{\left(V_{t}>0\right)}\right]+\cdots
\end{gathered}
$$

where $1_{(V>0)}$ indicates no default. The residual accruing to debt claimants upon default $R$ is the reorganized value of the firm ${ }^{9}$

$$
R_{t}^{L}=(1-\tau) f\left(K_{t} ; \theta_{t}\right)+\tau \delta K_{t}-I_{t}+\frac{1}{1+r} \mathrm{E}_{t}\left[V_{t+1}\right]
$$

When equity claimants default on their coupon payment, debt claimants receive the residual firm value and pay a default cost to reorganize the firm. ${ }^{10}$ Default triggers a reorganization, not an inefficient liquidation. The firm is subsequently recapitalized. Default therefore triggers two types of costs borne by debt claimants at reorganization: the deadweight default cost $X$ and a one-period forgone tax benefit $\tau c$. Consistent with the debt overhang literature, the default cost $X$ is assumed to be a fixed cost.

\footnotetext{
${ }^{9}$ By definition, the net residual $R^{L}\left(K_{t} ; \theta_{t}\right)-X$ accruing to debt claimants is always less than the no-default coupon payment $c$ accruing to debt claimants when default occurs (when $D_{t}^{L}+\frac{1}{1+r} E_{t}\left[V_{t+1}\right] \leq 0$ ). Using the definition of the residual $R^{L}\left(K_{t} ; \theta_{t}\right)$ where $D_{t}^{L}+\frac{1}{1+r} E_{t}\left[V_{t+1}\right]=R^{L}\left(K_{t} ; \theta_{t}\right)-(1-\tau) c$, default implies that $R^{L}\left(K_{t} ; \theta_{t}\right) \leq(1-\tau) c$. Given the tax benefit of debt $\tau>0, R^{L}\left(K_{t} ; \theta_{t}\right)<c$. Thus, $R^{L}\left(K_{t} ; \theta_{t}\right)-X<c$.

${ }^{10}$ In reality, debt claimants rarely manage firms in or emerging from bankruptcies. Debt claimants can be viewed as intermediaries who sell the reorganized firm value to a new group of equity claimants.
} 
The long-term debt is chosen initially to maximize the total firm value at time 0 . Because this one-time decision involves a tradeoff of expected tax benefit and default cost over an infinite number of periods, I do not characterize the decision with an Euler equation. Instead, the model is solved assuming a given value for the coupon $c$. I then iterate over values for the coupon $c$. The optimal coupon $c$ is the one that corresponds to the highest initial firm value.

With debt in place, the firm's problem becomes recursive. The firm maximizes its total value by choosing how much to invest $I_{t}$ after observing the long-term debt coupon $c$, last period's choice of capital stock $K_{t}$, and the beginning-of-the-period value for the income shock $\theta_{t}$. The total firm value $J^{L}$ is the sum of the equity $V$ and debt $L$ values. It consists of the after-tax income and depreciation tax shield net of investment, plus the tax benefit $\tau c$ if equity claimants do not default, minus the default cost $X$ if they default, plus the expected discounted firm value next period. The Bellman equation is

$$
\begin{gathered}
J^{L}\left(K_{t} ; \theta_{t}, c\right)=\max _{\left\{I_{t}\right\}} V_{t}+L_{t}=\max _{\left\{I_{t}\right\}}(1-\tau) f\left(K_{t} ; \theta_{t}\right)+\tau \delta K_{t}-I_{t} \\
+\tau c 1_{\left(V_{t}>0\right)}-X\left(1-1_{\left(V_{t}>0\right)}\right)+\frac{1}{1+r} \mathrm{E}_{t}\left[J^{L}\left(K_{t+1} ; \theta_{t+1}, c\right)\right]
\end{gathered}
$$

The firm's investment decision is characterized by

$$
\frac{1}{1+r} \mathrm{E}_{t}\left[(1-\tau) \theta_{t+1} \alpha K_{t+1}^{\alpha-1}+(1-(1-\tau) \delta)\right]-\frac{1}{1+r}(\tau c+X) \frac{\partial \Phi\left[\bar{\theta}^{L}\left(K_{t+1}, c\right)\right]}{\partial K_{t+1}}=1 .
$$

Equation (13) states that the firm invests up to the point where the cost of one unit of asset equals next period's expected discounted marginal product of capital. This marginal product is valued irrespective of the solvency of the firm, because the total firm value is being maximized. The investment proceeds accrue to equity claimants if default has not occurred, or to debt claimants if default has occurred.

Equation (13) also shows that the firm considers the benefit of not defaulting when making its investment decision. The firm knows that increasing its investment this period reduces its 
probability of defaulting next period. The effect of investment on the probability of defaulting,

$\frac{\partial \Phi\left[\bar{\theta}^{L}\left(K_{t+1}, c\right)\right]}{\partial K_{t+1}}$, is defined in the appendix. In the event of default, the firm forgoes a one-period tax benefit and pays the default $\operatorname{cost}(\tau c+X)$.

Without a tax benefit $\tau=0$ and a default $\operatorname{cost} X=0$, the firm's investment decision would not be affected by its capital structure, as in Modigliani and Miller, and its investment policy in equation (13) would revert to the policy of the unlevered firm in equation (5). With a tax benefit $\tau \neq 0$ or a default cost $X \neq 0$, the levered total-value-maximizing firm has the incentive to invest more than the unlevered firm to avoid the default costs $(\tau c+X)$. The equity claimants' underinvestment is expected to be higher using the levered total-value-maximizing firm benchmark than using the unlevered firm benchmark.

\subsubsection{Equity-value-maximizing Firm}

In this model, the firm cares about equity claimants only. The firm maximizes the equity value by choosing how much to invest $I_{t}$ after observing the long-term debt coupon $c$, last period's choice of capital stock $K_{t}$, and the beginning-of-the-period value for the income shock $\theta_{t}$. The Bellman equation is

$$
V\left(K_{t} ; \theta_{t}, c\right)=\max _{\left\{I_{t}\right\}} \max \left\{0, D_{t}+\frac{1}{1+r} \mathrm{E}_{t}\left[V\left(K_{t+1} ; \theta_{t+1}, c\right)\right]\right\}
$$

subject to the income, investment, and dividend equations (1), (2), and (8), and where the long-term debt coupon is chosen initially to maximize the total firm value at time 0 .

The firm's investment decision is characterized by

$$
\frac{1}{1+r} \mathrm{E}_{t}\left[\left\{(1-\tau) \theta_{t+1} \alpha K_{t+1}^{\alpha-1}+(1-(1-\tau) \delta)\right\} 1_{\left(V_{t+1}>0\right)}\right]=1
$$

Equation (15) differs from the unlevered firm benchmark of equation (5). The equity-valuemaximizing firm values next period's contribution to dividends in the no-default states only. The equity-value-maximizing firm therefore invests less than the unlevered firm. 
Equation (15) also differs from the total-value-maximizing firm benchmark of equation (13). Not only do equity claimants value next period's contribution to dividends in the no-default states only, but they do not bear any cost upon default (such as $\tau c+X$ for debt claimants) because of the limited liability protection. Comparing equations (13) and (15) suggests that the equityvalue-maximizing firm invests less than the total-value-maximizing firm. In equation (15), the marginal product of capital $(1-\tau) \theta_{t+1} \alpha K_{t+1}^{\alpha-1}+(1-(1-\tau) \delta)$ of the equity-value-maximizing firm is greater than $1+r$ on average, assuming that the no-default probability is less than one and its covariance with the marginal product is minimal. In equation (13), the marginal product of the total-value-maximizing firm is smaller than $1+r$ on average, given that investing more reduces the probability of defaulting next period. Because of decreasing returns to scale, a greater marginal product implies a smaller capital stock level. Equations (13) and (15) therefore show that the equity-value-maximizing firm invests less than total-firm-maximizing firm.

\subsection{Short-term Debt}

\subsubsection{Total-value-maximizing Firm}

This model is similar to the total-value-maximizing firm model with long-term debt but replaces long-term debt with short-term debt. The firm can now respond to its financing needs by issuing or retiring short-term debt every period. The new debt issue $\Delta B_{t+1}$ is the difference between the new debt level chosen this period $B_{t+1}$ and the beginning-of-the-period debt level $B_{t}$

$$
\Delta B_{t+1}=B_{t+1}-B_{t} .
$$

The short-term debt has a maturity of one period. Each period, the firm can roll over its existing debt $\Delta B_{t+1}=0$, retire some debt $\Delta B_{t+1}<0$, or issue more debt $\Delta B_{t+1}>0$ at the current short-term coupon rate $\iota_{t+1}$. 
Equation (7) still defines the equity value, but the sources and uses of funds equation now recognizes that dividends may be increased by a short-term debt issue

$$
D_{t}^{S}=(1-\tau) f\left(K_{t} ; \theta_{t}\right)+\tau \delta K_{t}-I_{t}+\Delta B_{t+1}-(1-\tau) \iota_{t} B_{t},
$$

where the superscript ${ }^{S}$ indicates a functional form specific to the case with short-term debt.

When making its short-term debt financing decisions, the firm must take into account the pricing schedule at which the debt can be financed. Debt claimants require a coupon rate $\iota_{t+1}$ such that the bond selling at par is fairly priced:

$$
\frac{1}{1+r} \mathrm{E}_{t}\left[\left(1+\iota_{t+1}\right) B_{t+1} 1_{\left(V_{t+1}>0\right)}\right]+\frac{1}{1+r} \mathrm{E}_{t}\left[\left(R_{t+1}^{S}-X\right)\left(1-1_{\left(V_{t+1}>0\right)}\right)\right]=B_{t+1},
$$

where the residual accruing to debt claimants upon default is

$$
R_{t}^{S}=(1-\tau) f\left(K_{t} ; \theta_{t}\right)+\tau \delta K_{t}-I_{t}+B_{t+1}+\frac{1}{1+r} \mathrm{E}_{t}\left[V_{t+1}\right]
$$

Equation (18) shows that debt claimants require a coupon rate such that one unit of debt lent to the firm equals next period's expected discounted payoff. The payoff on the debt claim consists of the face value and the coupon payment if equity claimants do not default on their debt obligation, or the net residual value if equity claimants default.

The income shock at which equity claimants trigger default on their short-term debt obligation $\bar{\theta}^{S}\left(K_{t}, B_{t}, \iota_{t}\right)$ is implicitly defined by

$$
\begin{gathered}
(1-\tau) \bar{\theta}^{S}\left(K_{t}, B_{t}, \iota_{t}\right) K_{t}^{\alpha}+(1-(1-\tau) \delta) K_{t}-K_{t+1}+B_{t+1}-\left(1+(1-\tau) \iota_{t}\right) B_{t} \\
+\frac{1}{1+r} \mathrm{E}_{t}\left[V_{t+1} \mid \theta_{t}=\bar{\theta}^{S}\left(K_{t}, B_{t}, \iota_{t}\right)\right]=0
\end{gathered}
$$

The firm maximizes the equity value subject to the fair bond pricing equation (18) by choosing how much to invest $I_{t}$ and how much debt to issue $\Delta B_{t+1}$ after observing the beginning-of-theperiod value for the income shock $\theta_{t}$ and last period's choices of capital stock $K_{t}$ and debt $B_{t}$, 
where the fair bond pricing constraint is substituted in the maximand and is summarized by the coupon rate schedule $\iota_{t+1}=\iota\left\{K_{t+1}, B_{t+1} ; \theta_{t}\right\}$.

The total firm value $J^{S}$ is the sum of the equity $V$ and debt $S$ values. It consists of the after-tax income and depreciation tax shield net of investment, plus the tax benefit if equity claimants do not default, minus the default cost if they default, plus the expected discounted firm value next period. The Bellman equation is

$$
\begin{aligned}
& J^{S}\left(K_{t}, B_{t} ; \theta_{t}\right)=\max _{\left\{I_{t}, \Delta B_{t+1}\right\}} V_{t}+S_{t}=\max _{\left\{I_{t}, \Delta B_{t+1}\right\}}(1-\tau) f\left(K_{t} ; \theta_{t}\right)+\tau \delta K_{t}-I_{t} \\
& \quad+\tau \iota\left\{K_{t}, B_{t} ; \theta_{t-1}\right\} B_{t} 1_{\left(V_{t}>0\right)}-X\left(1-1_{\left(V_{t}>0\right)}\right)+\frac{1}{1+r} \mathrm{E}_{t}\left[J^{S}\left(K_{t+1}, B_{t+1} ; \theta_{t+1}\right)\right]
\end{aligned}
$$

where the short-term debt value $S_{t}$ is

$$
S_{t}=\left(1+\iota\left\{K_{t}, B_{t} ; \theta_{t-1}\right\}\right) B_{t} 1_{\left(V_{t}>0\right)}+\left(R_{t}^{S}-X\right)\left(1-1_{\left(V_{t}>0\right)}\right) .
$$

The firm's investment decision is characterized by

$$
\begin{gathered}
\frac{1}{1+r} \mathrm{E}_{t}\left[(1-\tau) \theta_{t+1} \alpha K_{t+1}^{\alpha-1}+(1-(1-\tau) \delta)\right]+\frac{1}{1+r} \mathrm{E}_{t}\left[\tau B_{t+1} 1_{\left(V_{t+1}>0\right)}\right] \frac{\partial \iota\left\{K_{t+1}, B_{t+1} ; \theta_{t}\right\}}{\partial K_{t+1}} \\
-\frac{1}{1+r}\left(\tau \iota\left\{K_{t+1}, B_{t+1} ; \theta_{t}\right\} B_{t+1}+X\right)\left(\frac{\partial \Phi\left[\bar{\theta}^{S}\left(K_{t+1}, B_{t+1}, \iota_{t+1}\right)\right]}{\partial K_{t+1}}\right. \\
\left.+\frac{\partial \Phi\left[\bar{\theta}^{S}\left(K_{t+1}, B_{t+1}, \iota_{t+1}\right)\right]}{\partial \iota_{t+1}} \frac{\partial \iota\left\{K_{t+1}, B_{t+1} ; \theta_{t}\right\}}{\partial K_{t+1}}\right)=1,
\end{gathered}
$$

where the effects of investment on the firm's coupon rate and on the probability of defaulting are defined in the appendix.

Equation (23) states that the firm invests up to the point where the cost of one unit of capital equals next period's expected discounted marginal benefit. In contrast to equation (13) with longterm debt, equation (23) shows that the firm also accounts for the effects of its investment decision on next period's coupon rate requested by debt claimants through the term $\frac{\partial \iota\left\{K_{t+1}, B_{t+1} ; \theta_{t}\right\}}{\partial K_{t+1}}$.

The firm's optimal short-term debt level is characterized by 


$$
\begin{gathered}
\frac{1}{1+r} \mathrm{E}_{t}\left[\tau \iota\left\{K_{t+1}, B_{t+1} ; \theta_{t}\right\} 1_{\left(V_{t+1}>0\right)}\right]+\frac{1}{1+r} \mathrm{E}_{t}\left[\tau B_{t+1} 1_{\left(V_{t+1}>0\right)}\right] \frac{\partial \iota\left\{K_{t+1}, B_{t+1} ; \theta_{t}\right\}}{\partial B_{t+1}} \\
-\frac{1}{1+r}\left(\tau \iota\left\{K_{t+1}, B_{t+1} ; \theta_{t}\right\} B_{t+1}+X\right)\left(\frac{\partial \Phi\left[\bar{\theta}^{S}\left(K_{t+1}, B_{t+1}, \iota_{t+1}\right)\right]}{\partial B_{t+1}}\right. \\
\left.+\frac{\partial \Phi\left[\bar{\theta}^{S}\left(K_{t+1}, B_{t+1}, \iota_{t+1}\right)\right]}{\partial \iota_{t+1}} \frac{\partial \iota\left\{K_{t+1}, B_{t+1} ; \theta_{t}\right\}}{\partial B_{t+1}}\right)=0,
\end{gathered}
$$

where the effects of debt on the firm's coupon rate and on the probability of defaulting are defined in the appendix.

\subsubsection{Equity-value-maximizing Firm}

This model is similar to the equity-value-maximizing firm model with long-term debt but replaces long-term debt with short-term debt. As in all models, the debt policy is chosen to maximize the total firm value. It is the investment policy here that is chosen to maximize the equity value only. The firm's problem is sequential: each period the firm first chooses how much debt to issue $\Delta B_{t+1}$ and at what price $\iota_{t+1}$ to maximize the value to all claimants, and then chooses how much to invest $I_{t}$ to maximize the equity value without regard to the debt claims. Ignoring the debt already in place defines the overhang behavior.

The model is solved backwards. In the second stage, the investment decision is characterized taking the debt policy $\left(B_{t+1}\right.$ and $\left.\iota_{t+1}\right)$ as given. Both the debt level $B_{t+1}$ and the coupon rate $\iota_{t+1}$ are predetermined in the second stage, as they have been chosen in the first stage. Equity claimants maximize their value by choosing how much to invest $I_{t}$ after observing the beginning-of-the-period value for the income shock $\theta_{t}$, last period's choices of capital stock $K_{t}$ and debt $\left(B_{t}\right.$ and $\left.\iota_{t}\right)$, and the first stage predetermined choices of debt $\left(B_{t+1}\right.$ and $\left.\iota_{t+1}\right)$. The Bellman equation describing the firm's intertemporal investment problem is

$$
V\left(K_{t} ; B_{t+1}, \iota_{t+1}, B_{t}, \iota_{t}, \theta_{t}\right)=\max _{\left\{I_{t}\right\}} \max \left\{0, D_{t}+\frac{1}{1+r} \mathrm{E}_{t}\left[V\left(K_{t+1} ; B_{t+2}, \iota_{t+2}, B_{t+1}, \iota_{t+1}, \theta_{t+1}\right)\right]\right\}
$$


subject to income, investment, and dividend equations (1), (2), and (17).

The investment decision is characterized by

$$
\frac{1}{1+r} \mathrm{E}_{t}\left[\left\{(1-\tau) \theta_{t+1} \alpha K_{t+1}^{\alpha-1}+(1-(1-\tau) \delta)\right\} 1_{\left(V_{t+1}>0\right)}\right]=1
$$

Similar to equation (15) with long-term debt, the equity-value-maximizing investment policy with short-term debt shows that the firm disregards the effect of investment on the debt value. It values next period's contribution to dividends in the no-default states only.

In contrast to the total-value-maximizing investment policy of equation (23), the equity-valuemaximizing investment policy cannot include terms relating to the effect of investment on the coupon rate. By definition of overhang, investment cannot affect the coupon rate as the debt policy is determined prior to the investment decision. Equation (26) therefore has less terms than equation (23) because investment in (26) is chosen without the constraint of the fair bond pricing equation.

Equation (26) defines the second stage investment $K_{t+1}$ in terms of the first stage debt policy variables $\left(B_{t+1}, \iota_{t+1}\right)$ and the exogenous income shock $\theta_{t}$. Investment $K_{t+1}$ becomes an implicit function $K\left\{B_{t+1}, \iota_{t+1} ; \theta_{t}\right\}$ when choosing the optimal debt policy in the first stage.

In the first stage, the firm anticipates that equity claimants will later ignore debt claimants when choosing the investment policy $K_{t+1}=K\left\{B_{t+1}, \iota_{t+1} ; \theta_{t}\right\}$. The firm maximizes the equity value subject to the fair bond pricing equation (18) by choosing how much debt to issue $\Delta B_{t+1}$ after observing the beginning-of-the-period value for the income shock $\theta_{t}$, last period's choices of capital stock $K_{t}$ and debt $B_{t}$. The fair bond pricing constraint is substituted in the maximand and is summarized by the coupon rate schedule $\iota_{t+1}=\iota\left\{B_{t+1} ; \theta_{t}\right\}$.

Note that the coupon rate $\iota_{t+1}$ is chosen in the first stage. To see this, the problem could have been expressed as maximizing the equity value subject to the fair bond pricing equation (18) by choice of both the debt issue $\Delta B_{t+1}$ and the coupon rate $\iota_{t+1}$. In this latter formulation, the fair 
bond pricing constraint is not substituted into the maximand and therefore the coupon rate is not expressed as an implicit function summarizing the pricing equation.

The first stage coupon rate schedule is expressed only in terms of the simultaneously chosen debt level $B_{t+1}$ and the exogenous state variable $\theta_{t}: \iota_{t+1}=\iota\left\{B_{t+1} ; \theta_{t}\right\}$. Because the second stage investment $K_{t+1}$ is a function of the first stage debt policy, investment $K_{t+1}$ is not an extra variable to carry around in the first stage.

The Bellman equation describing the intertemporal debt problem is

$$
\begin{gathered}
J^{S}\left(B_{t} ; \theta_{t}\right)=\max _{\left\{\Delta B_{t+1}\right\}} V_{t}+S_{t} \\
=\max _{\left\{\Delta B_{t+1}\right\}}(1-\tau) f\left(K\left\{B_{t}, \iota\left\{B_{t} ; \theta_{t-1}\right\} ; \theta_{t-1}\right\} ; \theta_{t}\right)+\tau \delta K\left\{B_{t}, \iota\left\{B_{t} ; \theta_{t-1}\right\} ; \theta_{t-1}\right\}-I_{t} \\
+\tau \iota\left\{B_{t} ; \theta_{t-1}\right\} B_{t} 1_{\left(V_{t}>0\right)}-X\left(1-1_{\left(V_{t}>0\right)}\right)+\frac{1}{1+r} \mathrm{E}_{t}\left[J^{S}\left(B_{t+1} ; \theta_{t+1}\right)\right] .
\end{gathered}
$$

The short-term debt policy is characterized by

$$
\begin{aligned}
& \frac{1}{1+r} \mathrm{E}_{t}\left[\left\{(1-\tau) \theta_{t+1} \alpha K\left\{B_{t+1}, \iota\left\{B_{t+1} ; \theta_{t}\right\} ; \theta_{t}\right\}^{\alpha-1}+(1-(1-\tau) \delta)\right\}\right. \\
& \left.\left(\frac{\partial K\left\{B_{t+1}, \iota_{t+1} ; \theta_{t}\right\}}{\partial B_{t+1}}+\frac{\partial K\left\{B_{t+1}, \iota_{t+1} ; \theta_{t}\right\}}{\partial \iota_{t+1}} \frac{\partial \iota\left\{B_{t+1} ; \theta_{t}\right\}}{\partial B_{t+1}}\right)\right] \\
& +\frac{1}{1+r} \mathrm{E}_{t}\left[\tau \iota\left\{B_{t+1} ; \theta_{t}\right\} 1_{\left(V_{t+1}>0\right)}\right]+\frac{1}{1+r} \mathrm{E}_{t}\left[\tau B_{t+1} 1_{\left(V_{t+1}>0\right)}\right] \frac{\partial \iota\left\{B_{t+1} ; \theta_{t}\right\}}{\partial B_{t+1}} \\
& -\frac{1}{1+r}\left(\tau \iota\left\{B_{t+1} ; \theta_{t}\right\} B_{t+1}+X\right)\left\{\frac { \partial \Phi [ \overline { \theta } ^ { S } ( K _ { t + 1 } , B _ { t + 1 } , \iota _ { t + 1 } ) ] } { \partial K _ { t + 1 } } \left(\frac{\partial K\left\{B_{t+1}, \iota_{t+1} ; \theta_{t}\right\}}{\partial B_{t+1}}\right.\right. \\
& \left.\left.+\frac{\partial K\left\{B_{t+1}, \iota_{t+1} ; \theta_{t}\right\}}{\partial \iota_{t+1}} \frac{\partial \iota\left\{B_{t+1} ; \theta_{t}\right\}}{\partial B_{t+1}}\right)+\frac{\partial \Phi\left[\bar{\theta}^{S}\left(K_{t+1}, B_{t+1}, \iota_{t+1}\right)\right]}{\partial B_{t+1}}+\frac{\partial \Phi\left[\bar{\theta}^{S}\left(K_{t+1}, B_{t+1}, \iota_{t+1}\right)\right]}{\partial \iota_{t+1}} \frac{\partial \iota\left\{B_{t+1} ; \theta_{t}\right\}}{\partial B_{t+1}}\right\} \\
& =\left(\frac{\partial K\left\{B_{t+1}, \iota_{t+1} ; \theta_{t}\right\}}{\partial B_{t+1}}+\frac{\partial K\left\{B_{t+1}, \iota_{t+1} ; \theta_{t}\right\}}{\partial \iota_{t+1}} \frac{\partial \iota\left\{B_{t+1} ; \theta_{t}\right\}}{\partial B_{t+1}}\right) \text {. }
\end{aligned}
$$

Equation (28) of the equity-value-maximizing firm includes the same terms as in equation (24) of the total-value-maximizing firm: the expected tax benefit, the default cost, and the effects of the debt level on the firm's coupon rate and on the default probability. However, note that the effect of the debt level on the coupon rate, $\frac{\partial \iota\left\{B_{t+1} ; \theta_{t}\right\}}{\partial B_{t+1}}$, now accounts for the effects of the first stage debt policy on the second stage investment through the terms $\frac{\partial K\left\{B_{t+1}, \iota_{t+1} ; \theta_{t}\right\}}{\partial B_{t+1}}$ and $\frac{\partial K\left\{B_{t+1}, \iota_{t+1} ; \theta_{t}\right\}}{\partial \iota_{t+1}}$, 
as described in equation (45) of the appendix. In addition, equation (28) directly includes these effects. Equation (28) therefore contains additional terms because debt is chosen with the additional constraint of anticipating the subsequent investment decision of equity claimants.

\section{The Calibration}

The last four models cannot be solved analytically, but the solution is approximated numerically. The numerical method and its accuracy are described in the appendix. The method requires values for the model parameters. All theoretical firms are calibrated to $\tau=0.15, X=0.5, F=0.76$, $r=0.065, \alpha=0.25, \delta=0.14, \rho=0.6$, and $\sigma=0.14$. The calibration aims to match the leverage and investment statistics simulated from the equity-value-maximizing firm with short-term debt to the statistics observed in reality.

The tax rate $\tau$ is set to 0.15 to represent the tax benefit of debt net of personal taxes. The deadweight default cost of debt $X$ is calibrated to 0.5 . The value of 0.5 is chosen so that expected default costs with long-term debt and short-term debt bound Warner's (1977) estimate. Warner measures the direct bankruptcy costs of eleven railroad firms seven years prior to the petition date at one percent of firm value. As later reported in Tables 1 and 2, the expected default costs with long-term debt are lower than one percent and the costs with short-term debt are higher than one percent.

The fixed labor cost $F$ is calibrated to 0.76 so that the average leverage ratio of the equityvalue-maximizing firm with short-term debt is reasonable, near fifty percent. Fixed costs decrease the amount of debt that can be serviced by the firm. While U.S. firms have lower debt ratios, it is difficult for dynamic capital structure models to replicate such low levels. For example, Titman and Tsyplakov also obtain leverage ratios with dynamic debt around fifty percent. In addition, the calibration $F=0.76$ yields a realistic leverage ratio for the equity-value-maximizing firm with 
long-term debt at twenty-six percent.

Following Gomes (2001), the discount rate $r$ is set to 0.065 to match the real interest rate over the last century. The sensitivity of revenues to the capital stock $\alpha$ is set to 0.25 . When added to the sensitivity of revenues to labor (about two thirds during the post-war period), the firm's returns to scale are below one as documented in Burnside (1996). The depreciation rate $\delta$, the persistence $\rho$, and the volatility $\sigma$ are set to $0.14,0.6$, and 0.14 so that the equity-value-maximizing firm with short-term debt matches the mean (fifteen percent), autocorrelation (twenty-four percent) and the standard deviation (fourteen percent) of the investment ratio $I / K$. Although I calibrate my model to Gomes's estimated moments of the investment series, my calibration differs slightly from his ( $\alpha=0.3, \delta=0.12, \rho=0.62$, and $\sigma=0.15)$ because the two models are different.

The long-term coupon $c$ is chosen to maximize the ex-ante total firm value. The optimal coupon is 0.055 for the total-value-maximizing firm and 0.03 for the equity-value-maximizing firm.

Given these parameter values, the models are solved numerically as described in the appendix. The appendix also reports on the accuracy of the numerical solution. The resulting series $I_{t}$ and $V_{t}$, including $B_{t+1}$ and $\iota_{t+1}$ for models with short-term debt, are simulated from random outcomes of the income shock $\epsilon_{t}$. A sample of 500 different time series over 500 periods is generated for each model, where only the last twenty periods out of the 500 are examined. A firm is defined as a time series in which no default occurs (positive equity value $V_{t}>0$ ) for ten consecutive periods. About 0.4 percent of firms with long-term debt and 1.4 percent of firms with short-term debt experience default from periods eleven to twenty. ${ }^{11}$ I keep a final panel of 500 simulated firms over ten periods. 500 firms over ten years provide a reasonable description of the data available in COMPUSTAT.

\footnotetext{
${ }^{11}$ In the long-run, all simulated series experience default at some point. However, default in the model is a oneperiod event. Firms reorganized from last period's default do not differ from firms not in default last period. Both are owned by equity claimants who optimally decide on the optimal level of investment (and short-term debt). Likewise, firms in reality do not exist forever. Firms go through well-documented life cycles. Moreover, the model is not meant as a general equilibrium description of the economy. Firms in my model can default and reorganize but the whole economy cannot.
} 
One can collect data on firms for more than ten years. However, as the number of years increases, the number of surviving firms decreases.

\section{Results}

Tables 1 and 2 describe the overhang problem using three different panels of simulated firms: a panel of unlevered firms, a panel of total-value-maximizing firms, and a panel of equity-valuemaximizing firms. For each panel, the tables report the means and standard deviations of key variables, including the leverage ratio, the investment ratio, and the firm value. The leverage ratio is the debt value ( $L$ for long-term debt or $S$ for short-term debt) divided by the sum of equity $(V)$ and debt values. The investment ratio is investment $I$ divided by capital stock $K$. The firm value is the sum of equity and debt values. The means and standard deviations are computed for each firm in a panel. Tables 1 and 2 report the average of these two moments over all firms in a panel.

Firm value is then disaggregated into three components: the value from operations, the tax benefit, and the default cost. The value from operations is the expected discounted value derived from the firm's investment and production activities. The tax benefit is the expected discounted value of the interest payment deduction. The default cost is the expected discounted value of the deadweight default cost.

To quantify the overhang problem, the tables report the difference in values between the equitymaximizing firm and the benchmark firm, standardized by the value of the benchmark firm. I measure the debt overhang cost as the difference in values using the total-maximizing firm benchmark. Another interesting measure of underinvestment is the difference in values from operations using the unlevered firm benchmark.

The last piece of information contained in the tables is the average income shock across all three panels of firms. The sample excludes firm-year observations for which default occurs, because 
overhang is measured for firms not currently in default. Because of the sample selection, the average income shock is slightly larger than one. Comparing across tables, a higher income shock indicates a higher occurrence of default.

\subsection{Overhang with Long-term Debt}

\subsubsection{Descriptive Statistics}

Table 1 examines firms with long-term debt. The equity-value-maximizing firm has an average leverage ratio of 25.59 percent. The firm has an average investment ratio of 14.89 percent with an average standard deviation of 13.28 percent. Because model parameters are set so that the equityvalue-maximizing firm with short-term debt rather than with long-term debt matches the data, the average investment ratio of the firm with long-term debt happens to be close to the calibration target of 0.15 but its average standard deviation is lower than the target of 0.14 . Table 1 shows that the firm derives the bulk of its value, 96.33 percent, from its investment and production activities. The expected tax benefits account for 3.87 percent of its value. This percentage is lower than Graham's (2000) empirical estimate of the tax benefit at 9.7 percent of firm value. The expected default costs represent 0.20 percent. As targeted by the calibration, the expected discounted default costs are lower than the one percent direct bankruptcy cost measured by Warner.

The total-maximizing firm value is by definition higher than the equity-maximizing firm value $(2.1091>2.0185)$. If equity claimants could commit to maximizing total value, the firm would raise more funds from debt claimants. Accordingly, the leverage ratio of the total-value-maximizing firm is much higher than the leverage ratio of the equity-value-maximizing firm (45.57 percent > 25.59 percent). The larger leverage ratio generates larger expected tax benefits (6.52 percent $>3.87$ percent) and larger expected default costs (1.07 percent $>0.20$ percent $)$. The percentage of the firm value derived from investment and production activities is smaller for the total-value-maximizing 
firm than for the equity-value-maximizing firm (94.56 percent $<96.33$ percent). This does not indicate that the total-value-maximizing firm derives less value from investment and production. In fact, the smaller percentage (94.56 percent) of the larger total-maximizing firm value (2.1091) yields a larger value derived from investment and production activities. Investment ratios can also be misleading. The investment ratio is larger for the equity-value-maximizing firm than for the total-value-maximizing firm (14.89 percent $>14.59$ percent). The equity-value-maximizing firm invests less $I$ and generates a much lower capital stock $K$, resulting in a higher investment ratio $I / K$. The equity-value-maximizing firm therefore shows a larger investment ratio only because it has a smaller capital stock.

\subsubsection{Unlevered Firm Benchmark}

Underinvesting by the equity-value-maximizing firm generates a value loss from operations of 0.49 percent of the unlevered firm value. Equations (5) and (15) indicate that the equity-valuemaximizing firm invests less than the unlevered firm when default is likely. As expected, Figure 1 illustrates that the underinvestment occurs in lower income shocks where default becomes more likely.

Figure 1 plots the capital investment policy function $K_{t+1}$ averaged over the capital state variable $K_{t}$ at the discretized values of the income shock state variable $\theta_{t}$ for the three types of firms: the unlevered firm, the total-value-maximizing firm, and the equity-value-maximizing firm. In better income shocks when the probability of default is negligible, the unlevered firm and the equity-value-maximizing firm choose the same level of capital stock. Their decisions differ only in the worst income shocks, where the equity-value-maximizing firm invests less because the proceeds of that investment are likely to accrue to debt claimants upon default.

The value loss from operations of 0.49 percent is slightly lower than previously documented in the literature. Mello and Parsons examine a mine's decision whether or not to operate in a real 
options framework. They measure the value loss from operations at 0.8 percent of the unlevered firm value. They also generate the larger loss from a lower leverage ratio (18 percent). When equity claimants can vary their investment level through time, they underinvest only in the worst income shocks. In better income shocks, equity claimants invest more to take advantage of the improved marginal product of capital. The flexibility to change the investment level across income shocks reduces equity claimants' average underinvestment at a given debt level. In equilibrium, the firm is able to raise more funds from the debt market. The value loss from operations therefore turns out to be slightly lower than Mello and Parsons $(0.49$ percent $<0.8$ percent) and generated with a higher leverage ratio $(25.59$ percent $>18$ percent $)$.

\subsubsection{Total-value-maximizing Firm Benchmark}

Using the total-value-maximizing firm benchmark generates a larger value loss from operations. Underinvesting by the equity-value-maximizing firm generates a value loss from operations of 2.61 percent of the total-maximizing firm value.

Equation (13) shows that the total-value-maximizing firm takes into account two marginal benefits when deciding how much to invest. The first term on the left-hand-side of the equation shows that more investment contributes to next period's dividend through its marginal product of capital. The second term shows that more investment reduces the default probability. In better income shocks, the default probability is minimal and the firm increases its investment to take advantage of the improved marginal product of capital through the first term. As income shocks deteriorate, the firm invests less. In the worst income shocks, however, the firm invests more than warranted by the marginal product of capital to reduce its probability of default through

the second term. More investment, up to the point of not defaulting this period, generates more revenues next period, thereby reducing the probability of defaulting and the probability of losing the tax benefit for one period and paying the deadweight cost $(\tau c+X)$ upon default. The resulting 
capital investment decision $K_{t+1}$ of the total-value-maximizing firm is u-shaped across income shocks. In contrast, the decision of the unlevered firm depends solely on the marginal product of capital and is monotonically increasing with income shocks. The total-value-maximizing investment policy of equation (13) indeed differs from the unlevered investment policy of equation (5) by the second term, which reflects the incentive to invest more to avoid losing the one-period tax benefit and paying the deadweight cost $(\tau c+X)$ upon default. Ignoring the interaction between the firm's investment and financing decisions by using the unlevered firm benchmark therefore underestimates the debt overhang problem.

Figure 1 illustrates that, in better income shocks when the probability of default is negligible, the total-value-maximizing firm, the equity-value-maximizing firm, and the unlevered firm choose the same level of capital stock. Their decisions differ only in the worst income shocks. The total-valuemaximizing firm invests more than the unlevered firm (and the equity-value-maximizing firm) to reduce its probability of defaulting next period and therefore its probability of losing its tax benefit and paying the deadweight cost.

In addition to the value loss from operations, the equity-value-maximizing firm with its lower leverage than the total-value-maximizing firm also loses value from the lower expected tax benefits (2.85 percent), but gains value from the lower expected default costs ( 0.77 percent). Adding it up, the debt overhang cost measured by the loss in firm value averages to 4.70 percent of the total-maximizing firm value.

Note that the measure of debt overhang does not correspond to a specific realization of the state variables, but averages the percent value loss across the distribution of state variables generated in the panels of simulated firms. By Jensen's inequality, the average debt overhang cost (4.70 percent) is not equal to the average difference between the total-maximizing and equity-maximizing firm values $(2.1091-2.0185)$ divided by the average total-maximizing firm value (2.1091). 
The debt overhang cost of 4.70 percent is larger than reported in the existing literature. Mauer and Ott examine a firm's decision whether or not to expand operations using a real options framework. They measure the debt overhang cost to no more than 1.54 percent of the equitymaximizing firm value, when the total-value-maximizing and equity-value-maximizing firms pay the same coupon. Restating the cost in terms of the total-value-maximizing firm, their Table 9.3 shows an overhang cost of 1.32 percent of the total-maximizing firm value, with their basic calibration, a price of $\$ 2.50$, and when the total-value-maximizing firm and equity-value-maximizing firm pay the same coupon. ${ }^{12}$ When I set the coupon of the total-value-maximizing firm equal to that of the equity-value-maximizing firm at 0.03 instead of its optimal level at 0.055 , the total-maximizing firm has a lower value (2.0312 instead of 2.1091), representing an overhang cost of 0.80 percent of the total-maximizing firm value, well within the range of values obtained by Mauer and Ott.

In the real options framework of Mello and Parsons and Mauer and Ott, debt overhang occurs when equity claimants delay operating/expanding beyond the point that maximizes the total firm value. Equity claimants wait for a higher output price than optimal for the whole firm. For example, in Mauer and Ott, the total-value-maximizing firm exercises sooner $(\$ 2.78)$ than the unlevered firm (\$3.06), which exercises sooner than the equity-value-maximizing firm $(\$ 3.16)$. It is striking that the output price difference between the equity-value-maximizing firm $(\$ 3.16)$ and the total-value-maximizing firm $(\$ 2.78)$ is much larger than the difference between the equity-valuemaximizing firm $(\$ 3.16)$ and the unlevered firm $(\$ 3.06)$. Table 1 and Figure 1 similarly show that the underinvestment cost is much larger with the total-value-maximizing firm benchmark than with the unlevered firm benchmark.

When the total-value-maximizing firm is allowed to choose its optimal coupon, Mauer and Ott document an overhang cost of 2.15 percent of the total-maximizing firm value, up from 1.32 percent

\footnotetext{
${ }^{12}$ Table 9.3 reports values of 29.54 for the total-maximizing firm and 29.15 for the equity-maximizing firm, so that the difference divided by 29.54 is 1.32 percent.
} 
with their basic calibration and output price of $\$ 2.50{ }^{13}$ The larger overhang cost arises because the total-value-maximizing firm takes on a larger coupon than the equity-value-maximizing firm. The coupon payment increases about 30 percent from 1.76 to 2.30 . The percent increase in my coupon payment is even larger, about 83 percent from 0.03 to $0.055 .^{14}$ My larger overhang cost of 4.70 percent arises because the total-value-maximizing firm is able to support a larger coupon payment with investment flexibility.

To capitalize a larger expected tax benefit over all income shocks, the total-value-maximizing firm with long-term debt has the incentive to take on more debt than it could otherwise afford in the worst income shocks without investment flexibility. The firm with long-term debt cannot change its leverage to decrease it in bad income shocks and increase it as shocks improve. With investment flexibility, however, it can invest more in bad shocks, up to the point of not defaulting this period, to reduce the probability of defaulting next period. More investment generates more revenues next period, so that the firm may be able to avoid default and its associated costs. Therefore, when the firm can change its level of investment through time, it uses the flexibility to accumulate a larger tax benefit while managing its default probability.

In addition to Mauer and Ott and Mello and Parsons, Titman and Tsyplakov also quantify the overhang cost with long-term debt. Titman and Tsyplakov report that the equity-maximizing firm value differs from the total-maximizing firm value by 2.1 percent of the untaxed, unlevered firm value. When expressed as a percentage of the taxed and levered total-value-maximizing firm, their debt overhang cost increases to 2.9 percent. This cost is higher than Mauer and Ott's, but lower than my estimate. While Titman and Tsyplakov allow the firm to change its investment through time, the investment into the capital stock is irreversible. Because of the irreversibility,

\footnotetext{
${ }^{13}$ Table 9.5 reports values of 29.79 for the total-maximizing firm and 29.15 for the equity-maximizing firm, so that the difference divided by 29.79 is 2.15 percent.

${ }^{14}$ The two models do not share the same scale, so that only percentages are comparable.
} 
the total-value-maximizing firm's incentive near the default point to invest more in bad income shocks to reduce the default probability and its associated costs is mitigated. With reversibility, the total-value-maximizing firm may sell some of its capital as conditions improve from the very worst income shocks. With irreversibility, however, the firm cannot do so because it is restricted to maintain a minimal capital stock level. When this minimal capital stock level exceeds the level warranted by the marginal product of capital as shocks improve, the firm finds itself overcapitalized. Instead, the total-value-maximizing firm relaxes the irreversibility constraint by not investing as much in bad income shocks. Titman and Tsyplakov's debt overhang cost is thus smaller than my estimate.

In sum, debt overhang estimates increase from about 2 percent in Mauer and Ott with an irreversible decision whether or not to invest, to 2.9 percent in Titman and Tsyplakov with irreversible investments into the capital stock, to 4.70 percent with full investment flexibility. In terms of Figure 1, each added degree of flexibility allows the capital investment policy function of the total-value-

maximizing firm to distance itself from that of the unlevered firm in the lowest income shocks. When the firm has more flexibility in managing its default probability, the total-value-maximizing firm is able to accumulate a larger tax shield and compensates by investing more in lower income shocks to avoid default. The total-value-maximizing firm that benchmarks debt overhang is greatly affected by investment flexibility. More investment flexibility increases the debt overhang cost.

\subsection{Overhang with Short-term Debt}

\subsubsection{Descriptive Statistics}

Table 2 shows that firms with short-term debt have higher leverage ratios compared to firms with long-term debt. The average leverage ratio of equity-value-maximizing firms is 51.92 percent with short-term debt versus 25.59 percent with long-term debt. Likewise, the average leverage 
ratio of total-value-maximizing firms is 54.63 percent with short-term debt versus 45.57 percent with long-term debt.

The higher leverage ratios with short-term debt appear to be at odds with results from the existing literature. For example, in Titman and Tsyplakov, firms with short-term debt are less levered initially than firms with long-term debt. ${ }^{15}$ Their result obtains because it is more costly to decrease short-term debt than to increase it. In addition, because of the positive drift in the price process, Titman and Tsyplakov report that firms with short-term debt increase leverage over time, such that their leverage ratio is on average higher than the leverage ratio of firms with long-term debt. ${ }^{16}$ In my model, the initial leverage ratio is not different from the average leverage ratio. In accord with Titman and Tsyplakov, I obtain that average leverage ratios are higher with short-term debt than with long-term debt.

The equity-value-maximizing firm has a much higher leverage ratio with short-term debt than with long-term debt (51.92 percent $>25.59$ percent). With long-term debt, the equity-valuemaximizing firm cannot change its coupon payment through time. It therefore chooses a low leverage so that default and overhang are less likely to occur. With short-term debt, the equityvalue-maximizing firm also chooses a low level of debt in low income shocks, but it increases its leverage as income shocks improve to take advantage of the tax benefit. Averaging over all income shocks, the equity-value-maximizing firm with short-term debt produces a much higher leverage.

The total-value-maximizing firm also has a higher leverage ratio with short-term debt than with long-term debt (54.63 percent $>45.57$ percent), but the difference in leverage is not as large as for the equity-value-maximizing firm. With long-term debt, the total-value-maximizing firm already takes on a significant amount of debt because it considers the interaction between investment and

\footnotetext{
${ }^{15}$ Titman and Tsyplakov model short-term debt as a callable perpetuity, where firms can decrease their debt levels over time but can only do so by retiring debt at a specified rate.

${ }^{16}$ See Titman and Tsyplakov, page 17.
} 
financing decisions. The firm uses its investment flexibility to manage its probability of default. With short-term debt, the total-value-maximizing firm takes on a larger amount of debt because it can manage its probability of default more effectively with its debt policy. It chooses less debt in bad income shocks and increases its leverage as shocks improve. Averaging over all income shocks, the total-value-maximizing firm with short-term debt shows a higher leverage.

Firms with short-term debt not only have higher leverage ratios, but they also have higher investment ratios and consequently higher firm values. The equity-value-maximizing firm with short-term debt has an average investment ratio of 14.99 percent (versus 14.89 percent with longterm debt), and an average firm value of 2.0645 (versus 2.0185 with long-term debt). Likewise, the total-value-maximizing firm with short-term debt has an average investment ratio of 14.83 percent (versus 14.59 percent with long-term debt), and an average firm value of 2.1712 (versus 2.1091 with long-term debt).

The investment moments of the equity-value-maximizing firm, with a mean of 14.99 percent and a standard deviation of 13.86 percent, are very close to 15 percent and 14 percent targeted by the calibration. Table 2 shows that the firm derives the bulk of its value, 94.36 percent, from investment and production activities. The expected tax benefits account for a significant portion of its value, at 8.90 percent. This percentage is close to Graham's empirical estimate of the tax benefit at 9.7 percent of firm value. The expected default costs represent 3.25 percent. As targeted by the calibration, the expected default costs are higher than Warner's direct bankruptcy cost estimate of one percent.

Similar to the case with long-term debt, the total-maximizing firm value is by definition higher than the equity-maximizing firm value $(2.1712>2.0645)$. The percentage of the firm value derived from investment and production activities for the total-value-maximizing firm is very close to that for the equity-value-maximizing firm (94.52 percent and 94.36 percent). Because the leverage ratio 
of the total-value-maximizing firm is slightly higher than the leverage ratio of the equity-valuemaximizing firm, so are the expected tax benefits (9.08 percent $>8.90$ percent) and the expected default costs $(3.60$ percent $>3.25$ percent).

Short-term debt allows firms to vary their coupon rate over time. Accordingly, leverage ratios are more volatile with short-term debt than with long-term debt, as indicated by the standard deviations in Tables 1 and 2 for the equity-value-maximizing firm (10.32 percent $>6.67$ percent) and for the total-value-maximizing firm (10.14 percent $>9.65$ percent). Along with more volatile leverage ratios, investment ratios and firm values are also slightly more volatile.

\subsubsection{Unlevered Firm Benchmark}

Underinvesting by the equity-value-maximizing firm with short-term debt generates a value loss from operations of 0.46 percent of the unlevered firm value. This loss is similar to the value loss from operations of 0.49 percent with long-term debt. While the value loss from operations remains about the same on average, Figure 2 shows that it is in part redistributed from bad income shocks to better income shocks. With short-term debt, the equity-value-maximizing firm decreases its leverage in bad income shocks, reducing its default probability and underinvestment compared to the case with long-term debt. The firm however increases its leverage in better income shocks to take advantage of the tax benefit, raising its default probability and underinvestment compared to the case with long-term debt. Because the equity-value-maximizing firm with short-term debt increases its leverage ratio with income shocks, default remains a non-negligible possibility across all income shocks. Figure 2 illustrates that the different types of firms with short-term debt no longer choose the same level of capital stock in any income shock. Compared to the unlevered firm, the equity-value-maximizing firm slightly underinvests in all income shocks.

\subsubsection{Total-value-maximizing Firm Benchmark}


Using the total-value-maximizing firm benchmark again generates a larger value loss from operations than using the unlevered firm benchmark. As discussed before, the unlevered firm benchmark underestimates the overhang problem because it does not take into account the totalvalue-maximizing firm's incentive near the default point to invest more to avoid losing the tax benefit and paying the deadweight $\operatorname{cost}(\tau c+X)$ upon default. Underinvesting by the equity-valuemaximizing firm with short-term debt generates a value loss from operations of 4.98 percent of the total-maximizing firm value.

The value loss from operations using the total-value-maximizing firm benchmark is larger with short-term debt than with long-term debt (4.98 percent $>2.61$ percent). This indicates that the difference in investment policies between the total-value-maximizing firm and the equity-valuemaximizing firm is larger with short-term debt than with long-term debt. Figure 2 indeed illustrates that the total-value-maximizing firm always invests more than the equity-value-maximizing firm. Compared to the unlevered firm, the equity-value-maximizing firm invests slightly less in all income shocks while the total-value-maximizing firm invests more in all income shocks. The total-valuemaximizing firm with short-term debt chooses a low leverage in bad income shocks and increases it as shocks improve. The firm does not need to invest as much in bad income shocks to manage its probability of default because it can also reduce its leverage. In better income shocks, the firm levers up to take advantage of the tax benefit. The firm increases leverage to such an extent that default remains a concern. The total-value-maximizing firm therefore maintains its incentive to invest more to reduce the probability of default in all income shocks.

The debt overhang cost, measured by the loss in firm value, averages to 5.12 percent of the total-maximizing firm value. Most of the value loss, 4.98 percent, is accounted by investment and production activities. Because the equity-value-maximizing firm has a slightly lower leverage than the total-value-maximizing firm, the equity-value-maximizing firm loses a small amount from the 
expected tax benefits (0.66 percent), but gains a small amount from the lower expected default costs $(0.52$ percent $)$.

Figures 1 and 2 show the underinvestment by the equity-value-maximizing firm (the bottom line) compared to the total-value-maximizing firm (the top line). With short-term debt, firms are able to manage the default probability by adjusting their leverage. Firms decrease their leverage in bad income shocks, reducing the default probability and overhang compared to the case with long-term debt. Firms however increase their leverage in better income shocks to take advantage of the tax benefit. Because firms with short-term debt greatly increase their leverage with income shocks, default remains a non-negligible possibility across all income shocks. Consequently, the overhang problem persists even in better income shocks.

In the worst income shocks, Figures 1 and 2 show that the underinvestment is larger with longterm debt than with short-term debt, consistent with Myers' solution to the overhang problem by shortening the debt maturity. In better income shocks, however, Figure 1 shows that long-term debt overhang disappears while Figure 2 shows that short-term debt overhang remains present. Averaging over all shocks, the magnitude of the short-term debt overhang is similar to that of the long-term debt overhang, as reported in Tables 1 and 2. Contrary to conventional wisdom, the overhang problem is not mitigated by shortening the debt maturity when debt is optimally chosen every period.

Figure 3 graphs the average debt overhang cost at representative income shock realizations, $\theta_{t}$. The 500 simulated income shock series over 10 periods are divided into ten groups, from the lowest 500 outcomes to the highest 500 outcomes, and averaged to form ten income shock grid points. At each of these ten income shock points, the average of the corresponding 500 debt overhang costs is computed and reported in Figure 3.

While the average debt overhang cost has about the same magnitude for the two types of debt 
(4.70 percent and 5.12 percent), the pattern across income shocks is different. With long-term debt, default is more likely to occur in bad income shocks. As Figure 3 shows, overhang can be as high as 9.71 percent in the very worst income shocks. With short-term debt, the default probability remains present in all income shocks. In contrast to overhang with long-term debt, overhang with short-term debt is not as costly in bad income shocks (6.75 percent), but it does not decrease as rapidly as shocks improve. In the best income shocks, overhang still represents 3.98 percent with short-term debt but only 2.43 percent with long-term debt.

The overhang cost with short-term debt of 5.12 percent of the total-maximizing firm value appears lower than Titman and Tsyplakov's estimate with short-term debt. Titman and Tsyplakov report that the equity-value-maximizing firm value differs from the total-value-maximizing firm value by 5.9 percent of the untaxed, unlevered firm value. ${ }^{17}$ When expressed in terms of the taxed and levered total-value-maximizing firm value, Titman and Tsyplakov's estimate increases to 6.57 percent. Their estimate of a firm with short-term debt however assumes an average maturity of 20 years, far from my short-term debt maturity of one year. With a 20-year maturity on debt that can only to be retired over time at a specified rate, the short-term debt structure of Titman and Tsyplakov is compounding the long-term debt overhang of their long-maturity debt structure with the short-term debt overhang of their additional flexibility that renews the firm's incentive to underinvest. When Titman and Tsyplakov examine the robustness of their overhang cost over different maturities, their debt overhang cost decreases from 5.9 percent of the untaxed, unlevered firm value with a 20-year maturity to 2.2 percent with a five-year maturity. ${ }^{18}$ With a shorter maturity, more of the debt is being issued at the fair market price every period, mitigating the long-term debt overhang.

\footnotetext{
${ }^{17}$ Surprisingly, their large dynamic debt overhang does not appear to be a significant determinant of capital structure. Their initial leverage ratios for the equity-value-maximizing firm and the total-value-maximizing firm are very similar at 48.5 and 48.7 percent.

${ }^{18}$ See Titman and Tsyplakov, Table 6.
} 
In sum, Titman and Tsyplakov quantify the debt overhang problem to approximately 2 percent of their untaxed, unlevered firm value with long-term debt or with the five-year maturity debt. Similarly, my estimate of the debt overhang problem also does not vary much across the two types of debt (about 5 percent of the total-maximizing firm value). The difference in magnitude between the estimates again arises from the different degrees of investment flexibility, where more investment flexibility significantly increases the debt overhang cost.

\subsection{Comparative Statics}

The comparative statics section identifies firm characteristics that magnify the debt overhang problem. The parameters of interest are: the depreciation rate $\delta$, the income shock persistence $\rho$, the shock volatility $\sigma$, the sensitivity of revenues to the capital stock $\alpha$, the tax rate $\tau$, and the deadweight cost $X$. Tables 3 and 4 document the results of changing one parameter value at a time, otherwise holding the calibration constant.

When capital structure can respond to the parameter change, the results with long-term debt in Table 3 and with short-term debt in Table 4 are qualitatively similar. Instead, a more informative experiment is performed. For the case of long-term debt in Table 3, the coupon is held at its optimal ex ante level of 0.03 for the equity-value-maximizing firm and 0.055 for the total-valuemaximizing firm. Table 3 therefore describes the effects of a change in firm characteristics taking the long-term debt coupon rate as given. In contrast, Table 4 describes the effects of a change in firm characteristics accounting for the short-term adjustment in capital structure.

Note that the comparative static results with respect to the persistence $\rho$ and volatility $\sigma$ parameters are generated while keeping the unconditional mean of the income shock constant. The shock process used to produce the comparative static results is:

$$
\ln \theta_{t+1}=\rho \ln \theta_{t}+\sigma \epsilon_{t+1}+(1-\rho)\left\{\frac{1}{2}\left(\frac{0.14}{1-0.6}\right)^{2}-\frac{1}{2}\left(\frac{\sigma}{1-\rho}\right)^{2}\right\}
$$


where the benchmark persistence is 0.6 and the benchmark standard deviation is 0.14 .

\subsubsection{Long-term Debt, Holding the Coupon Constant}

An increase in the depreciation rate $\delta$ accelerates the rate at which the firm's capital stock becomes obsolete. This greater cost depresses firm values and makes default more probable given the fixed level of long-term debt. In better income shocks, both the total-value-maximizing firm and the equity-value-maximizing firm invest less. More precisely, the portion of the capital investment policy function that is identical to both firms in better shocks shifts down. In the worst income shocks when default becomes likely, the equity-value-maximizing firm invests even less, while the total-value-maximizing firm invests even more to avoid forgoing the tax benefit and paying the default cost. ${ }^{19}$ The investment decisions of the two firms diverge more in bad income shocks, resulting in a larger debt overhang cost, as reported in Table 3.

An increase in persistence $\rho$ increases the probability that a low (high) income shock occurs next period given the low (high) income shock this period. In better income shocks, both firms invest increasing amounts as the income shock improves. In the worst income shocks when the larger probability of default is more likely to persist, the equity-value-maximizing firm invests even less and the total-value-maximizing firm invests even more. The investment policies of the two firms again diverge more in bad income shocks, resulting in a larger debt overhang cost.

An increase in volatility $\sigma$ makes default more likely. Default occurs in a wider range of low income shocks. The equity-value-maximizing firm facing low shocks responds by investing even less, while the total-value-maximizing firm invests even more in order to avoid losing its tax benefit and paying the deadweight cost upon default. The investment policies of the two firms again diverge more in bad income shocks, leading to a larger debt overhang cost. This result is contrary to Mauer and Ott, where an increase in volatility leads to a smaller overhang cost. In Mauer and Ott's real

\footnotetext{
${ }^{19}$ Note that Table 3 reports an increase in the investment ratio $I / K$, but only because the capital stock level $K$ decreases more than the investment level $I$.
} 
options framework, an increase in volatility increases the value of the option to expand to such an extent that the increased value makes default less likely.

An increase in the sensitivity of revenues to the capital stock $\alpha$ implies that the firm can rely more on its capital stock to provide revenues next period. Default becomes less likely. In better income shocks, both the total-value-maximizing firm and the equity-value-maximizing firm invest more. The capital investment policy functions shift up. In the worst income shocks, the equity-value-maximizing firm does not underinvest as much compared to the unlevered firm and the total-value-maximizing firm does not invest as much. The two investment decisions diverge less from each other in bad income shocks, resulting in a lower debt overhang cost.

An increase in the tax rate $\tau$ has two effects. It decreases the after-tax marginal product of capital. This lower productivity depresses firm values and makes default more probable. An increase in the tax rate also increases the tax benefit, which has the opposite effect on firm values and default probabilities. With the long-term coupon taken as given, the effect of the marginal product dominates. In better income shocks, both the total-value-maximizing firm and the equityvalue-maximizing firm invest less. More precisely, the capital investment policy functions shift down. In the worst income shocks when default becomes likely, the equity-value-maximizing firm invests even less because default is more probable, while the total-value-maximizing firm invests even more to avoid forgoing its larger tax benefit upon default. Once again, the investment decisions of the two firms diverge more in bad income shocks, and the debt overhang cost increases. In Mauer and Ott, the effects of the marginal product and the tax benefit presumably cancel each other out, so that the overhang is relatively insensitive to the tax rate.

An increase in the deadweight $\operatorname{cost} X$ makes default more costly. The default cost does not affect the leverage ratios much, as the long-term coupon is held constant. When investing, the equity-value-maximizing firm does not take into account the cost borne by debt claimants upon 
default. Only the total-value-maximizing firm does. In the worst income shocks, the total-valuemaximizing firm invests even more to avoid paying the larger deadweight cost upon default. The investment decisions of the two firms diverge more in bad income shocks, resulting in a larger debt overhang cost. This result is consistent with Mauer and Ott who also obtain that an increase in the bankruptcy cost increases the debt overhang cost.

\subsubsection{Short-term Debt}

For the case of short-term debt in Table 4, changes in firm characteristics have the same effect as before, except for the endogenous response of the firm's capital structure. Changes that prompt firms to increase their optimal debt levels are associated with larger debt overhang problems.

An increase in the depreciation rate $\delta$, accelerating the rate at which the firm's capital stock becomes obsolete, depresses firm values and makes default more probable. Firms re-establish a comfortable default probability by decreasing their leverage. Less debt leads to a lower overhang cost. This result is contrary to Titman and Tsyplakov, who obtain that an increase in the depreciation rate increases the overhang cost. In their framework, a higher depreciation rate relaxes the investment irreversibility constraint, so that the total-value-maximizing firm can invest more near the default point to reduce the probability of default and its associated costs. Titman and Tsyplakov's comparative static result indicates that their overhang cost increases when the irreversibility constraint is relaxed.

An increase in persistence $\rho$ increases the probability that a low (high) income shock occurs next period given the low (high) income shock this period. Firms choose a lower debt level in bad income shocks and increase their debt level more aggressively as income shocks improve. Averaging over all income shocks, leverage is lower on average, yielding a lower overhang cost.

An increase in volatility $\sigma$ makes default more likely. Firms reduce their default probability by decreasing their leverage. Less debt leads in a lower overhang cost. 
An increase in the sensitivity of revenues to the capital stock $\alpha$ implies that firms can rely more on their capital stock to provide revenues next period. Default becomes less likely. Firms take advantage of this increased productivity by increasing their leverage, generating a larger overhang cost.

An increase in the tax rate $\tau$ still has two effects. It decreases the after-tax marginal product of capital. The lower productivity depresses firm values and makes default more probable. An increase in the tax rate also increases the tax benefit, which has the opposite effect on firm values and default probabilities. With short-term debt, the effect of the tax benefit dominates. Firms increase their leverage to take advantage of the tax benefit, resulting in a larger overhang cost.

An increase in the deadweight $\operatorname{cost} X$ makes default more costly. Firms react by decreasing their leverage. Less debt is again associated with a lower overhang cost. This result is consistent with Titman and Tsyplakov who also obtain a lower overhang cost with a larger distress cost.

\section{Conclusion}

Since Myers, it has been well known that equity claimants underinvest in the presence of risky debt. My quantitative analysis produces two results. First, the debt overhang problem, measured with the total-value-maximizing firm benchmark, is larger with a more flexible investment policy. Second, a firm's capital structure influences the distribution of the debt overhang problem over investment opportunities. With long-term debt, equity claimants underinvest mostly in bad income shocks. With short-term debt, equity claimants do not underinvest as much in bad income shocks, but they continue to underinvest as shocks improve. Firms lever up to take advantage of the tax benefit, thereby maintaining equity claimants' incentive to underinvest.

From the empirical literature, it is well known that equity claimants underinvest to a greater extent when investment opportunities are deteriorating. Lang, Ofek, and Stulz (1996) and Hen- 
nessy provide empirical evidence on the investment behavior of firms facing poor investment opportunities. An empirical investigation of firms' investment behavior as it varies with investment opportunities, investment flexibility, and the type of capital structure would be useful.

\section{Acknowledgements}

This paper is based on my Ph.D. dissertation; I am indebted to Rob Heinkel and Burton Hollifield for their supervision. I would also like to thank Paul Beaudry, Martin Boileau, Gerry Garvey, Rick Green, Charles Himmelberg, Eric Hughson, Deborah Lucas, Tony Smith, Tan Wang, Jaime Zender, Lu Zhang, two anonymous referees, the editor (Wouter Den Haan), as well as seminar participants at the 1998 WFA Meetings, the 1999 Intertemporal Asset Pricing Conference, ASU, UBC, CMU, CU Boulder, Columbia, Laval, Maryland, McGill, Northwestern, Penn State, Queen's, Toronto, Utah, Waterloo, and York for helpful comments. Financial support from SSHRC and UBC is gratefully acknowledged.

\section{Appendix A. Effects of the Firm's Decisions on the Probabilities of Default}

The firm's investment $I$ and short-term debt policy ( $\Delta B$ and $\iota$ ) affect the probability of defaulting $\Phi[\bar{\theta}]$

$$
\begin{gathered}
\frac{\partial \Phi\left[\bar{\theta}_{t+1}\right]}{\partial K_{t+1}}=\phi\left[\bar{\theta}_{t+1}\right] \frac{\partial \bar{\theta}_{t+1}}{\partial K_{t+1}}<0 \\
\frac{\partial \Phi\left[\bar{\theta}_{t+1}\right]}{\partial B_{t+1}}=\phi\left[\bar{\theta}_{t+1}\right] \frac{\partial \bar{\theta}_{t+1}}{\partial B_{t+1}}>0 \\
\frac{\partial \Phi\left[\bar{\theta}_{t+1}\right]}{\partial \iota_{t+1}}=\phi\left[\bar{\theta}_{t+1}\right] \frac{\partial \bar{\theta}_{t+1}}{\partial \iota_{t+1}}>0
\end{gathered}
$$

where $\phi$ is the log-normal probability density function. 
The default point $\bar{\theta}_{t+1}$ decreases with more investment but increases with a higher debt level or with a higher coupon rate

$$
\begin{aligned}
\frac{\partial \bar{\theta}_{t+1}}{\partial K_{t+1}} & =-\left.\frac{V_{K_{t+1}}}{V_{\theta_{t+1}}}\right|_{\bar{\theta}_{t+1}}<0 \\
\frac{\partial \bar{\theta}_{t+1}}{\partial B_{t+1}} & =-\left.\frac{V_{B_{t+1}}}{V_{\theta_{t+1}}}\right|_{\bar{\theta}_{t+1}}>0 \\
\frac{\partial \bar{\theta}_{t+1}}{\partial \iota_{t+1}} & =-\left.\frac{V_{t_{t+1}}}{V_{\theta_{t+1}}}\right|_{\bar{\theta}_{t+1}}>0,
\end{aligned}
$$

where

$$
\begin{array}{cc}
V_{K_{t+1}}= & (1-\tau) \theta_{t+1} \alpha K_{t+1}^{\alpha-1}+(1-(1-\tau) \delta)>0 \\
V_{B_{t+1}}= & -\left(1+(1-\tau) \iota_{t+1}\right)<0 \\
V_{\iota t+1}= & -(1-\tau) B_{t+1}<0 .
\end{array}
$$

Numerical solutions indicate that a higher technology state increases the equity value, but the magnitude of this effect depends on the economic environment modeled. In the total-valuemaximizing firm model with long-term debt,

$$
V_{\theta_{t}}=(1-\tau) K_{t}^{\alpha}+\frac{1}{1+r} \mathrm{E}_{t}\left[V_{\theta_{t+1}} 1_{\left(V_{t+1}>0\right)} \frac{\partial \theta_{t+1}}{\partial \theta_{t}}\right]
$$

In the total-value-maximizing firm model with short-term debt,

$$
\begin{aligned}
V_{\theta_{t}}= & (1-\tau) K_{t}^{\alpha}+\frac{1}{1+r} \mathrm{E}_{t}\left[\tau B_{t} 1_{\left(V_{t+1}>0\right)} \frac{\partial \iota\left\{K_{t+1}, B_{t+1} ; \theta_{t}\right\}}{\partial \theta_{t}}\right]+\frac{1}{1+r} \mathrm{E}_{t}\left[V_{\theta_{t+1}} \frac{\partial \theta_{t+1}}{\partial \theta_{t}}\right] \\
& -\frac{1}{1+r}\left(\tau \iota\left\{K_{t+1}, B_{t+1} ; \theta_{t}\right\} B_{t+1}+X\right) \frac{\partial \Phi\left[\bar{\theta}^{S}\left(K_{t+1}, B_{t+1}, \iota_{t+1}\right)\right]}{\partial \iota t} \frac{\partial \iota\left\{K_{t+1}, B_{t+1} ; \theta_{t}\right\}}{\partial \theta_{t}}
\end{aligned}
$$

Finally, in the equity-value-maximizing firm model with short-term debt,

$$
\begin{aligned}
& V_{\theta_{t}}=(1-\tau) K\left\{B_{t}, \iota\left\{B_{t} ; \theta_{t-1}\right\} ; \theta_{t-1}\right\}^{\alpha}-\left(\frac{\partial K\left\{B_{t+1}, \iota_{t+1} ; \theta_{t}\right\}}{\partial \iota_{t+1}} \frac{\partial \iota\left\{B_{t+1} ; \theta_{t}\right\}}{\partial \theta_{t}}+\frac{\partial K\left\{B_{t+1}, \iota_{t+1} ; \theta_{t}\right\}}{\partial \theta_{t}}\right) \\
& +\frac{1}{1+r} \mathrm{E}_{t}\left[\tau B_{t+1} 1_{\left(V_{t+1}>0\right)} \frac{\partial \iota\left\{B_{t+1} ; \theta_{t}\right\}}{\partial \theta_{t}}\right]+\frac{1}{1+r} \mathrm{E}_{t}\left[\left\{(1-\tau) \theta_{t+1} \alpha K\left\{B_{t+1}, \iota\left\{B_{t+1} ; \theta_{t}\right\} ; \theta_{t}\right\}^{\alpha-1}\right.\right.
\end{aligned}
$$




$$
\begin{gathered}
\left.+(1-(1-\tau) \delta)\}\left(\frac{\partial K\left\{B_{t+1}, \iota_{t+1} ; \theta_{t}\right\}}{\partial \iota_{t+1}} \frac{\partial \iota\left\{B_{t+1} ; \theta_{t}\right\}}{\partial \theta_{t}}+\frac{\partial K\left\{B_{t+1}, \iota_{t+1} ; \theta_{t}\right\}}{\partial \theta_{t}}\right)\right]+\frac{1}{1+r} \mathrm{E}_{t}\left[V_{\theta_{t+1}} \frac{\partial \theta_{t+1}}{\partial \theta_{t}}\right] \\
-\frac{1}{1+r}\left(\tau \iota\left\{B_{t+1} ; \theta_{t}\right\} B_{t+1}+X\right)\left\{\frac{\partial \Phi\left[\bar{\theta}^{S}\left(K_{t+1}, B_{t+1}, \iota_{t+1}\right)\right]}{\partial \iota_{t+1}} \frac{\partial \iota\left\{B_{t+1} ; \theta_{t}\right\}}{\partial \theta_{t}}+\frac{\partial \Phi\left[\bar{\theta}^{S}\left(K_{t+1}, B_{t+1}, \iota_{t+1}\right)\right]}{\partial K_{t+1}}\right. \\
\left.\left(\frac{\partial K\left\{B_{t+1}, \iota_{t+1} ; \theta_{t}\right\}}{\partial \iota_{t+1}} \frac{\partial \iota\left\{B_{t+1} ; \theta_{t}\right\}}{\partial \theta_{t}}+\frac{\partial K\left\{B_{t+1}, \iota_{t+1} ; \theta_{t}\right\}}{\partial \theta_{t}}\right)\right\} .
\end{gathered}
$$

\section{Appendix B. Effects of the Firm's Decisions on the Short-term Coupon Rate}

Totally differentiating the fair bond pricing equation (18) yields

$$
\begin{gathered}
\frac{\partial \iota\left\{K_{t+1}, B_{t+1} ; \theta_{t}\right\}}{\partial K_{t+1}}=-\left(\frac{1}{1+r} \mathrm{E}_{t}\left[\left\{(1-\tau) \theta_{t+1} \alpha K_{t+1}^{(\alpha-1)}+(1-(1-\tau) \delta)\right\}\left(1-1_{\left(V_{t+1}>0\right)}\right)\right]\right. \\
\left.-\frac{1}{1+r}\left(\tau \iota_{t+1} B_{t+1}+X\right) \frac{\partial \Phi\left[\bar{\theta}^{S}\left(K_{t+1}, B_{t+1}, \iota_{t+1}\right)\right]}{\partial K_{t+1}}\right) \\
/\left(\frac{1}{1+r} \mathrm{E}_{t}\left[B_{t+1} 1_{\left(V_{t+1}>0\right)}\right]-\frac{1}{1+r}\left(\tau \iota_{t+1} B_{t+1}+X\right) \frac{\partial \Phi\left[\bar{\theta}^{S}\left(K_{t+1}, B_{t+1}, \iota_{t+1}\right)\right]}{\partial \iota_{t+1}}\right)
\end{gathered}
$$

and

$$
\begin{gathered}
\frac{\partial \iota\left\{K_{t+1}, B_{t+1} ; \theta_{t}\right\}}{\partial B_{t+1}}=-\left(\frac{1}{1+r} \mathrm{E}_{t}\left[\left(1+\iota_{t+1}\right) 1_{\left(V_{t+1}>0\right)}\right]-1\right. \\
\left.-\frac{1}{1+r}\left(\tau \iota_{t+1} B_{t+1}+X\right) \frac{\partial \Phi\left[\bar{\theta}^{S}\left(K_{t+1}, B_{t+1}, \iota_{t+1}\right)\right]}{\partial B_{t+1}}\right) \\
/\left(\frac{1}{1+r} \mathrm{E}_{t}\left[B_{t+1} 1_{\left(V_{t+1}>0\right)}\right]-\frac{1}{1+r}\left(\tau \iota_{t+1} B_{t+1}+X\right) \frac{\partial \Phi\left[\bar{\theta}^{S}\left(K_{t+1}, B_{t+1}, \iota_{t+1}\right)\right]}{\partial \iota_{t+1}}\right) .
\end{gathered}
$$

$\theta_{t}$ is not a decision, but its effect on the short-term coupon rate is needed for computing $V_{\theta_{t}}$.

$$
\begin{gathered}
\frac{\partial \iota\left\{K_{t+1}, B_{t+1} ; \theta_{t}\right\}}{\partial \theta_{t}}=-\left(\frac{1}{1+r} \mathrm{E}_{t}\left[V_{\theta_{t+1}}\left(1-1_{\left(V_{t+1}>0\right)}\right) \frac{\partial \theta_{t+1}}{\partial \theta_{t}}\right]\right) \\
/\left(\frac{1}{1+r} \mathrm{E}_{t}\left[B_{t+1} 1_{\left(V_{t+1}>0\right)}\right]-\frac{1}{1+r}\left(\tau \iota_{t+1} B_{t+1}+X\right) \frac{\partial \Phi\left[\bar{\theta}^{S}\left(K_{t+1}, B_{t+1}, \iota_{t+1}\right)\right]}{\partial \iota_{t+1}}\right) .
\end{gathered}
$$

The above equations apply to the total-value-maximizing firm model with short-term debt. However, when the firm disregards debt claimants as in the equity-value-maximizing firm model, the effect of the short-term debt policy $\left(B_{t+1}\right.$ and $\left.\iota_{t+1}\right)$ on investment $K_{t+1}$ must be taken into 
account

$$
\begin{gathered}
\frac{\partial \iota\left\{B_{t+1} ; \theta_{t}\right\}}{\partial B_{t+1}}=-\left(\frac{1}{1+r} \mathrm{E}_{t}\left[\left(1+\iota_{t+1}\right) 1_{\left(V_{t+1}>0\right)}\right]-1\right. \\
+\frac{1}{1+r} \mathrm{E}_{t}\left[\left\{(1-\tau) \theta_{t+1} \alpha K\left\{B_{t+1}, \iota_{t+1} ; \theta_{t}\right\}^{\alpha-1}+(1-(1-\tau) \delta)\right\}\left(1-1_{\left(V_{t+1}>0\right)}\right) \frac{\partial K\left\{B_{t+1}, \iota_{t+1} ; \theta_{t}\right\}}{\partial B_{t+1}}\right] \\
\left.-\frac{1}{1+r}\left(\tau \iota_{t+1} B_{t+1}+X\right)\left(\frac{\partial \Phi\left[\bar{\theta}^{S}\left(K_{t+1}, B_{t+1}, \iota_{t+1}\right)\right]}{\partial B_{t+1}}+\frac{\partial \Phi\left[\bar{\theta}^{S}\left(K_{t+1}, B_{t+1}, \iota_{t+1}\right)\right]}{\partial K_{t+1}} \frac{\partial K\left\{B_{t+1}, \iota_{t+1} ; \theta_{t}\right\}}{\partial B_{t+1}}\right)\right) \\
/\left(\frac{1}{1+r} \mathrm{E}_{t}\left[B_{t+1} 1_{\left(V_{t+1}>0\right)}\right]\right. \\
+\frac{1}{1+r} \mathrm{E}_{t}\left[\left\{(1-\tau) \theta_{t+1} \alpha K\left\{B_{t+1}, \iota_{t+1} ; \theta_{t}\right\}^{\alpha-1}+(1-(1-\tau) \delta)\right\}\left(1-1_{\left(V_{t+1}>0\right)}\right) \frac{\partial K\left\{B_{t+1}, \iota_{t+1} ; \theta_{t}\right\}}{\partial \iota_{t+1}}\right] \\
\left.-\frac{1}{1+r}\left(\tau \iota_{t+1} B_{t+1}+X\right)\left(\frac{\partial \Phi\left[\bar{\theta}^{S}\left(K_{t+1}, B_{t+1}, \iota_{t+1}\right)\right]}{\partial \iota_{t+1}}+\frac{\partial \Phi\left[\bar{\theta}^{S}\left(K_{t+1}, B_{t+1}, \iota_{t+1}\right)\right]}{\partial K_{t+1}} \frac{\partial K\left\{B_{t+1}, \iota_{t+1} ; \theta_{t}\right\}}{\partial \iota_{t+1}}\right)\right) \\
\frac{\partial \iota\left\{B_{t+1} ; \theta_{t}\right\}}{\partial \theta_{t}}=-\left(\frac{1}{1+r} \mathrm{E}_{t}\left[V_{\theta_{t+1}}\left(1-1\left(V_{t+1}>0\right)\right) \frac{\partial \theta_{t+1}}{\partial \theta_{t}}\right]\right. \\
+\frac{1}{1+r} \mathrm{E}_{t}\left[\left\{(1-\tau) \theta_{t+1} \alpha K\left\{B_{t+1}, \iota_{t+1} ; \theta_{t}\right\}^{\alpha-1}+(1-(1-\tau) \delta)\right\}\left(1-1_{\left(V_{t+1}>0\right)}\right) \frac{\partial K\left\{B_{t+1}, \iota_{t+1} ; \theta_{t}\right\}}{\partial \theta_{t}}\right] \\
\left.\frac{1}{1+r}\left(\tau \iota_{t+1} B_{t+1}+X\right) \frac{\partial \Phi\left[\bar{\theta}^{S}\left(K_{t+1}, B_{t+1}, \iota_{t+1}\right)\right]}{\partial K_{t+1}} \frac{\partial K\left\{B_{t+1}, \iota_{t+1} ; \theta_{t}\right\}}{\partial \theta_{t}}\right) \\
/\left(\frac{1}{1+r} \mathrm{E}_{t}\left[B_{t+1} 1_{\left(V_{t+1}>0\right)}\right]\right. \\
+\frac{1}{1+r} \mathrm{E}_{t}\left[\left\{(1-\tau) \theta_{t+1} \alpha K\left\{B_{t+1}, \iota_{t+1} ; \theta_{t}\right\}^{\alpha-1}+(1-(1-\tau) \delta)\right\}\left(1-1_{\left(V_{t+1}>0\right)} \frac{\partial K\left\{B_{t+1}, \iota_{t+1} ; \theta_{t}\right\}}{\partial \iota_{t+1}}\right]\right. \\
-\frac{1}{1+r}\left(\tau \iota_{t+1} B_{t+1}+X\right)\left(\frac{\partial \Phi\left[\bar{\theta}^{S}\left(K_{t+1}, B_{t+1}, \iota_{t+1}\right)\right]}{\partial \iota_{t+1}}+\frac{\partial \Phi\left[\bar{\theta}^{S}\left(K_{t+1}, B_{t+1}, \iota_{t+1}\right)\right]}{\partial K_{t+1}} \frac{\left.\partial K\left\{B_{\left.t+1, \iota_{t+1} ; \theta_{t}\right\}}\right)\right)}{\partial \iota_{t+1}}\right)
\end{gathered}
$$

\section{Appendix C. Effects of the Firm's First-stage Debt Policy on the Second-stage}

\section{Investment Decision}

When the firm chooses an investment policy that maximizes the equity value but disregards the debt value, debt claimants adjust their behavior accordingly before they decide how much to lend to the firm. The effects of the first-stage debt policy on the second-stage investment decision are obtained from totally differentiating equation (26)

$$
\frac{\partial K\left\{B_{t+1}, \iota_{t+1} ; \theta_{t}\right\}}{\partial B_{t+1}}=\frac{1}{1+r}\left\{(1-\tau) \bar{\theta}^{S}\left(K_{t+1}, B_{t+1}, \iota_{t+1}\right) \alpha K_{t+1}^{\alpha-1}+(1-(1-\tau) \delta)\right\}
$$




$$
\begin{gathered}
\frac{\partial \Phi\left[\bar{\theta}^{S}\left(K_{t+1}, B_{t+1}, \iota_{t+1}\right)\right]}{\partial B_{t+1}} /\left(\frac{1}{1+r} \mathrm{E}_{t}\left[(1-\tau) \theta_{t+1} \alpha(\alpha-1) K_{t+1}^{\alpha-2} 1_{\left(V_{t+1}>0\right)}\right]\right. \\
\left.-\frac{1}{1+r}\left\{(1-\tau) \bar{\theta}^{S}\left(K_{t+1}, B_{t+1}, \iota_{t+1}\right) \alpha K_{t+1}^{\alpha-1}+(1-(1-\tau) \delta)\right\} \frac{\partial \Phi\left[\bar{\theta}^{S}\left(K_{t+1}, B_{t+1}, \iota_{t+1}\right)\right]}{\partial K_{t+1}}\right) \\
\frac{\partial K\left\{B_{\left.t+1, \iota_{t+1} ; \theta_{t}\right\}}\right.}{\partial \iota_{t+1}}=\frac{1}{1+r}\left\{(1-\tau) \bar{\theta}^{S}\left(K_{t+1}, B_{t+1}, \iota_{t+1}\right) \alpha K_{t+1}^{\alpha-1}+(1-(1-\tau) \delta)\right\} \\
\frac{\partial \Phi\left[\bar{\theta}^{S}\left(K_{t+1}, B_{t+1}, \iota_{t+1}\right)\right]}{\partial \iota_{t+1}} /\left(\frac{1}{1+r} \mathrm{E}_{t}\left[(1-\tau) \theta_{t+1} \alpha(\alpha-1) K_{t+1}^{\alpha-2} 1_{\left(V_{t+1}>0\right)}\right]\right. \\
\left.-\frac{1}{1+r}\left\{(1-\tau) \bar{\theta}^{S}\left(K_{t+1}, B_{t+1}, \iota_{t+1}\right) \alpha K_{t+1}^{\alpha-1}+(1-(1-\tau) \delta)\right\} \frac{\partial \Phi\left[\bar{\theta}^{S}\left(K_{t+1}, B_{t+1}, \iota_{t+1}\right)\right]}{\partial K_{t+1}}\right)
\end{gathered}
$$

$\theta_{t}$ is not a debt policy, but its effect on the second period investment level is needed for computing $\frac{\partial \iota\left\{B_{t+1} ; \theta_{t}\right\}}{\theta_{t}}$ and $V_{\theta_{t}}$.

$$
\begin{gathered}
\frac{\partial K\left\{B_{\left.t+1, \iota_{t+1} ; \theta_{t}\right\}}\right.}{\partial \theta_{t}}=-\frac{1}{1+r} \mathrm{E}_{t}\left[(1-\tau) \alpha K_{t+1}^{\alpha-1} 1_{\left(V_{t+1}>0\right)} \frac{\partial \theta_{t+1}}{\partial \theta_{t}}\right] \\
/\left(\frac{1}{1+r} \mathrm{E}_{t}\left[(1-\tau) \theta_{t+1} \alpha(\alpha-1) K_{t+1}^{\alpha-2} 1_{\left(V_{t+1}>0\right)}\right]\right. \\
\left.-\frac{1}{1+r}\left\{(1-\tau) \bar{\theta}^{S}\left(K_{t+1}, B_{t+1}, \iota_{t+1}\right) \alpha K_{t+1}^{\alpha-1}+(1-(1-\tau) \delta)\right\} \frac{\partial \Phi\left[\bar{\theta}^{S}\left(K_{t+1}, B_{t+1}, \iota_{t+1}\right)\right]}{\partial K_{t+1}}\right)
\end{gathered}
$$

\section{Appendix D. Numerical Method}

The model is solved numerically using finite element methods as described in Coleman's (1990) algorithm. The policy functions $K_{t+1}, B_{t+1}, \iota_{t+1}$, and $V_{t}$ are approximated by piecewise linear interpolants of the state variables $K_{t}, B_{t}, \iota_{t}$, and $\theta_{t}$. Since the beginning-of-the-period debt variables, $B_{t}$ and $\iota_{t}$, do not appear in the Euler equations, the state space reduces to two dimensions: $K_{t}$ and

$\theta_{t}$. This grid consists of twenty uniformly-spaced points for each of these two state variables. The numerical integration involved in computing expectations is approximated with a Gauss-Hermite quadrature rule of ten nodes.

The approximation coefficients of the piecewise linear interpolants are chosen by collocation, i.e., to satisfy the relevant system of equations at all grid points. The approximated policy interpolants are substituted in the equations, and the coefficients are chosen such that the residuals are set to 
zero at all grid points. The time-stepping algorithm is used to find these root coefficients. Given initial coefficient values for all grid points, the time-stepping algorithm finds the optimal coefficients that minimize the residuals at one grid point, taking coefficients at other grid points as given. In turn, optimal coefficients for all grid points are determined. The iteration over coefficients stops when the maximum deviation of optimal coefficients from their previous values is lower than a specified tolerance level, e.g., 0.0001.

Table 5 documents the accuracy of the numerical solutions of the models with debt financing. For each model, Table 5 reports two measures of accuracy for a panel of $N=500$ simulated firms over $T=100,500$, and 1000 periods. The first measure of accuracy is the maximal absolute residual within 95 percent of firm-year observations. For models with long-term debt, this maximal absolute residual is smaller than $9 \times 10^{-6}$. Models with short-term debt do not perform as well, as their maximal absolute residual is smaller than $2.41 \times 10^{-5}$. For both types of debt, the total-valuemaximizing firm model shows smaller residuals than the equity-value-maximizing firm model.

The second measure of accuracy is the test developed by Den Haan and Marcet (1994), using the covariance estimator of Newey and West (1987). In accord with Den Haan and Marcet, my accuracy test results do not appear to be sensitive to the choice of instrument variables, which consist of the constant and state variables. Table 5 reports the percentage of Chi-square test values that fall in the lower 2.5 percent tail of the distribution and the percentage of test values that find themselves in the higher 2.5 percent tail of the distribution. The sample size of $T=100$ periods does not perform well across all four models. For example, 2.8 percent of test values computed from the equity-value-maximizing model with long-term debt fall in the 2.5 percent lower tail while an enormous 20.2 percent of test values find themselves in the 2.5 percent higher tail of the distribution. In larger samples of $T=500$ and $T=1000$ periods, the accuracy improves but is not perfect. There typically remain more test values in the higher tail of the distribution than in the 
lower tail.

\section{References}

Bernanke, B., Gertler, M., 1990. Financial fragility and economic performance. Quarterly Journal of Economics 105, 87-114.

Bernanke B., Gertler, M., 1989. Agency costs, net worth, and business fluctuations. American Economic Review 79, 14-31.

Brennan, M.J., Schwartz, E.S., 1984. Optimal financial policy and firm valuation. Journal of Finance 39, 593-609.

Brennan, M.J., Schwartz, E.S., 1978. Corporate income taxes, valuation, and the problem of optimal capital structure. Journal of Business 51, 103-114.

Burnside, C., 1996. Production function regressions, returns to scale and externalities. Journal of Monetary Economics 37, 177-201.

Calomiris, C.W., Hubbard, R.G., 1990. Firm heterogeneity, internal finance, and 'credit rationing.' Economic Journal 100, 90-104.

Coleman, W.J.II, 1990. Solving the stochastic growth model by policy-function iteration. Journal of Business and Economic Statistics 8, 27-29.

Dammon, R.M., Senbet, L.W., 1988. The effect of taxes and depreciation on corporate investment and financial leverage. Journal of Finance 43, 357-373.

Décamps, J.-P., Faure-Grimaud, A., 2002. Excessive continuation and dynamic agency costs of debt. European Economic Review 46, 1623-1644.

Den Haan, W.J., Marcet, A., 1994. Accuracy in simulations. The Review of Economic Studies 61, $3-17$. 
Dotan, A., Ravid, S.A., 1985. On the interaction of real and financial decisions of the firm under uncertainty. Journal of Finance 40, 501-517.

Ericsson, J., 2000. Asset substitution, debt pricing, optimal leverage and optimal maturity. Finance $21,39-69$.

Faig, M., Shum, P.M., 1999. Irreversible investment and endogenous financing: An evaluation of corporate tax effects. Journal of Monetary Economics 43, 143-171.

Fischer, E.O., Heinkel, R., Zechner, J., 1989. Dynamic capital structure choice: Theory and tests. Journal of Finance 44, 19-40.

Froot, K.A., Scharfstein, D.S., Stein, J.C., 1993. Risk management: Coordinating corporate investment and financing policies. Journal of Finance 48, 1629-1658.

Gomes, J.F., 2001. Financing investment. American Economic Review 91, 1263-1285.

Graham, J.R., 2000. How big are the tax benefits of debt? Journal of Finance 55, 1901-1941.

Hennessy, C.A., 2004. Tobin's Q, debt overhang, and investment. Journal of Finance 59, 1717-1742.

Kane, A., Marcus, A.J., McDonald, R.L., 1985. Debt policy and the rate of return premium to leverage. Journal of Financial and Quantitative Analysis 20, 479-499.

Kane, A., Marcus, A.J., McDonald, R.L., 1984. How big is the tax advantage to debt? Journal of Finance 39, 841-855.

Lang, L., Ofek, E., Stulz, R.M., 1996. Leverage, investment, and firm growth. Journal of Financial Economics 40, 3-29.

Leland, H.E., 1998. Agency costs, risk management, and capital structure. Journal of Finance 53, 1213-1243. 
Leland, H.E., 1994. Corporate debt value, bond covenants, and optimal capital structure. Journal of Finance 49, 1213-1252.

Leland, H.E., Toft, K.B., 1996. Optimal capital structure, endogenous bankruptcy, and the term structure of credit spreads. Journal of Finance 51, 987-1019.

Mauer, D.C., Ott, S.H., 2000. Agency costs, underinvestment, and optimal capital structure: The effect of growth options to expand, in Brennan, M.J., Trigeorgis, L. (Eds.), Project flexibility, agency, and competition, Oxford University Press, New York, pp. 151-179.

Mayer, C., 1986. Corporation tax, finance and the cost of capital. Review of Economic Studies 53, 93-112.

Mella-Barral, P., Perraudin, W., 1997. Strategic debt service. Journal of Finance 52, 531-556.

Mello, A.S., Parsons, J.E., 1992. Measuring the agency cost of debt. Journal of Finance 47, 1887-1904.

Modigliani, F., Miller, M.H., 1958. The cost of capital, corporation finance and the theory of investment. American Economic Review 48, 261-297.

Morellec, E., 2004. Can managerial discretion explain observed leverage ratios? Review of Financial Studies 17, 257-294.

Myers, S.C., 1977. Determinants of corporate borrowing. Journal of Financial Economics 5, 147175.

Myers, S.C., Majluf, N.S., 1984. Corporate financing and investment decisions when firms have information that investors do not have. Journal of Financial Economics 13, 187-221.

Newey, W.K., West, K.D., 1987. A simple, positive semi-definite, heteroskedasticity and autocorrelation consistent covariance matrix. Econometrica 55, 703-708. 
Parrino, R., Poteshman, A.M., Weisbach, M.S., 2005. Measuring investment distortions when risk-averse managers decide whether to undertake risky projects, Financial Management 34, 21-60. Parrino, R., Weisbach, M.S., 1999. Measuring investment distortions arising from stockholderbondholder conflicts. Journal of Financial Economics 53, 3-42.

Titman, S., Tsyplakov, S., 2003. A dynamic model of optimal capital structure. University of South Carolina and University of Texas at Austin working paper.

Warner, J., 1977. Bankruptcy costs: Some evidence. Journal of Finance 32, 337-348.

Wiggins, J.B., 1990. The relation between risk and optimal debt maturity and the value of leverage. Journal of Financial and Quantitative Analysis 25, 377-386. 


\section{Table 1: Overhang with Long-term Debt}

\begin{tabular}{|c|ccc|}
\hline & $\begin{array}{c}\text { Observable: } \\
\text { Equity-value-max } \\
\text { Firm }\end{array}$ & $\begin{array}{c}\text { Benchmark: } \\
\text { Total-value-max } \\
\text { Firm }\end{array}$ & $\begin{array}{c}\text { Alternative Benchmark: } \\
\text { Unlevered Firm }\end{array}$ \\
\hline Leverage Ratio & $25.59 \%$ & $45.57 \%$ & \\
$L /(V+L)$ & $(0.0667)$ & $(0.0965)$ & 0 \\
& & & $(0)$ \\
Investment Ratio & $14.89 \%$ & $14.59 \%$ & $14.81 \%$ \\
$I / K$ & $(0.1328)$ & $(0.1087)$ & $(0.1269)$ \\
Firm Value & 2.0185 & 2.1091 & 1.9583 \\
$(V+L)$ & $(0.4479)$ & $(0.4318)$ & $(0.4433)$ \\
Percentage from: & & & $100 \%$ \\
Value from Operations & $96.33 \%$ & $94.56 \%$ & $0 \%$ \\
Tax Benefit & $3.87 \%$ & $6.52 \%$ & $0 \%$ \\
Default Cost & $-0.20 \%$ & $-1.07 \%$ & \\
Difference in: & & & $3.18 \%$ \\
Firm Values & & & $-0.49 \%$ \\
Talues from Operations & & $-4.70 \%$ & $-0.34 \%$ \\
Tax Benefits & & $-2.61 \%$ & \\
Default Costs & & $-2.85 \%$ & \\
Income Shock & & $0.77 \%$ & \\
& & & \\
& & & \\
\hline
\end{tabular}

Note: Leverage Ratio is the long-term debt value $L$ divided by Firm Value; Investment Ratio, investment $I$ divided by capital stock $K$; and Firm Value, the sum of equity $V$ and debt $L$ values. Value from Operations is the expected discounted value of the firm's investment and production activities; Tax Benefit is the expected discounted value of the interest payment deduction; Default Cost is the expected discounted value of the deadweight default cost $X$. The Difference in Firm Values is measured by the difference in firm values $V+L$ between the equity-value-maximizing firm and the benchmark firm over the benchmark firm value. Mean values are reported in the table, with standard deviations in parenthesis. 
Table 2: Overhang with Short-term Debt

\begin{tabular}{|c|c|c|c|}
\hline & $\begin{array}{c}\text { Observable: } \\
\text { Equity-value-max } \\
\text { Firm }\end{array}$ & $\begin{array}{c}\text { Benchmark: } \\
\text { Total-value-max } \\
\text { Firm }\end{array}$ & $\begin{array}{l}\text { Alternative Benchmark: } \\
\text { Unlevered Firm }\end{array}$ \\
\hline $\begin{array}{l}\text { Leverage Ratio } \\
\qquad S /(V+S)\end{array}$ & $\begin{array}{l}51.92 \% \\
(0.1032)\end{array}$ & $\begin{array}{l}54.63 \% \\
(0.1014)\end{array}$ & $\begin{array}{c}0 \\
(0)\end{array}$ \\
\hline $\begin{array}{l}\text { Investment Ratio } \\
\qquad I / K\end{array}$ & $\begin{array}{l}14.99 \% \\
(0.1386)\end{array}$ & $\begin{array}{l}14.83 \% \\
(0.1265)\end{array}$ & $\begin{array}{l}14.83 \% \\
(0.1264)\end{array}$ \\
\hline $\begin{array}{c}\text { Firm Value } \\
(V+S) \\
\text { Percentage from: }\end{array}$ & $\begin{array}{l}2.0645 \\
(0.4578)\end{array}$ & $\begin{array}{c}2.1712 \\
(0.4668)\end{array}$ & $\begin{array}{c}1.9587 \\
(0.4417)\end{array}$ \\
\hline $\begin{array}{c}\text { Value from Operations } \\
\text { Tax Benefit } \\
\text { Default Cost }\end{array}$ & $\begin{array}{l}94.36 \% \\
8.90 \% \\
-3.25 \%\end{array}$ & $\begin{array}{l}94.52 \% \\
9.08 \% \\
-3.60 \%\end{array}$ & $\begin{array}{c}100 \% \\
0 \% \\
0 \%\end{array}$ \\
\hline $\begin{array}{c}\text { Difference in: } \\
\text { Firm Values } \\
\text { Values from Operations } \\
\text { Tax Benefits } \\
\text { Default Costs }\end{array}$ & & $\begin{array}{c}-5.12 \% \\
-4.98 \% \\
-0.66 \% \\
0.52 \%\end{array}$ & $\begin{array}{c}5.49 \% \\
-0.46 \% \\
9.39 \% \\
-3.43 \%\end{array}$ \\
\hline Income Shock & 1.0192 & & \\
\hline
\end{tabular}

Note: Leverage Ratio is the short-term debt value $S$ divided by Firm Value; Investment Ratio, investment $I$ divided capital stock $K$; and Firm Value, the sum of equity $V$ and debt $S$ values. Value from Operations is the expected discounted value of the firm's investment and production activities; Tax Benefit is the expected discounted value of the interest payment deduction; Default Cost is the expected discounted value of the deadweight default cost $X$. The Difference in Firm Values in measured by the difference in firm values $V+S$ between the equity-value-maximizing firm and the benchmark firm over the benchmark firm value. Mean values are reported in the table, with standard deviations in parenthesis. 


\section{Table 3: Overhang with Long-term Debt for Different Calibrations, Holding the Coupon Constant}

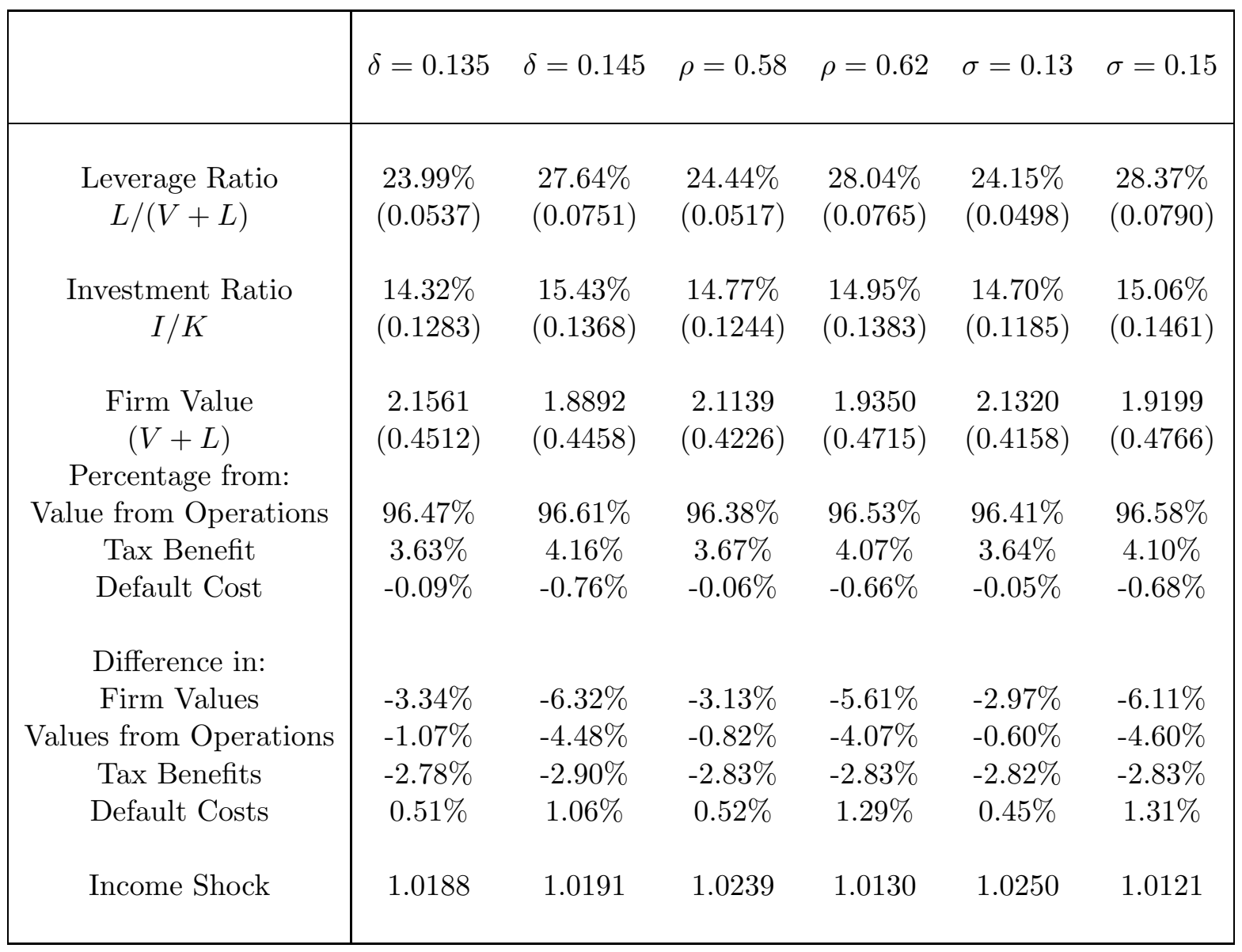

Note: Leverage Ratio is the long-term debt value $L$ divided by Firm Value; Investment Ratio, investment $I$ divided by capital stock $K$; and Firm Value, the sum of equity $V$ and debt $L$ values. Value from Operations is the expected discounted value of the firm's investment and production activities; Tax Benefit is the expected discounted value of the interest payment deduction; Default Cost is the expected discounted value of the deadweight default cost $X$. The Difference in Firm Values is measured by the difference in firm values $V+L$ between the equity-value-maximizing firm and the total-value-maximizing firm over the total-value-maximizing firm value. When the capital structure can respond to parameter changes, results with long-term debt in this table and with short-term debt in the next table are qualitatively similar. Instead, a more informative experiment is performed. The long-term debt coupon is held at its optimal ex ante level of 0.03 for the equityvalue-maximizing firm and 0.055 for the total-value-maximizing firm. 


\section{Table 3: Overhang with Long-term Debt for Different Calibrations, Holding the Coupon Constant (Continued)}

\begin{tabular}{|c|c|c|c|c|c|c|}
\hline & $\alpha=0.24$ & $\alpha=0.26$ & $\tau=0.125$ & $\tau=0.175$ & $X=0.1$ & $X=1.0$ \\
\hline $\begin{array}{c}\text { Leverage Ratio } \\
L /(V+L)\end{array}$ & $\begin{array}{l}26.41 \% \\
(0.0809)\end{array}$ & $\begin{array}{l}24.19 \% \\
(0.0565)\end{array}$ & $\begin{array}{l}24.70 \% \\
(0.0635)\end{array}$ & $\begin{array}{l}25.83 \% \\
(0.0778)\end{array}$ & $\begin{array}{l}25.64 \% \\
(0.0618)\end{array}$ & $\begin{array}{l}25.18 \% \\
(0.0689)\end{array}$ \\
\hline $\begin{array}{l}\text { Investment Ratio } \\
\qquad I / K\end{array}$ & $\begin{array}{l}15.13 \% \\
(0.1485)\end{array}$ & $\begin{array}{l}14.86 \% \\
(0.1307)\end{array}$ & $\begin{array}{l}14.86 \% \\
(0.1305)\end{array}$ & $\begin{array}{l}14.99 \% \\
(0.1397)\end{array}$ & $\begin{array}{l}14.89 \% \\
(0.1328)\end{array}$ & $\begin{array}{l}14.89 \% \\
(0.1328)\end{array}$ \\
\hline $\begin{array}{c}\text { Firm Value } \\
\quad(V+L) \\
\text { Percentage from: }\end{array}$ & $\begin{array}{c}1.8989 \\
(0.4420)\end{array}$ & $\begin{array}{c}2.1389 \\
(0.4600)\end{array}$ & $\begin{array}{c}2.0857 \\
(0.4585)\end{array}$ & $\begin{array}{c}1.9450 \\
(0.4395)\end{array}$ & $\begin{array}{c}2.0241 \\
(0.4475)\end{array}$ & $\begin{array}{c}2.0127 \\
(0.4485)\end{array}$ \\
\hline $\begin{array}{c}\text { Value from Operations } \\
\text { Tax Benefit } \\
\text { Default Cost }\end{array}$ & $\begin{array}{l}97.29 \% \\
4.10 \% \\
-1.39 \%\end{array}$ & $\begin{array}{l}96.48 \% \\
3.67 \% \\
-0.15 \%\end{array}$ & $\begin{array}{l}97.20 \% \\
3.15 \% \\
-0.36 \%\end{array}$ & $\begin{array}{l}96.14 \% \\
4.70 \% \\
-0.85 \%\end{array}$ & $\begin{array}{l}96.19 \% \\
3.88 \% \\
-0.07 \%\end{array}$ & $\begin{array}{l}96.85 \% \\
3.91 \% \\
-0.76 \%\end{array}$ \\
\hline $\begin{array}{c}\text { Difference in: } \\
\text { Firm Values } \\
\text { Values from Operations } \\
\text { Tax Benefits } \\
\text { Default Costs }\end{array}$ & $\begin{array}{l}-6.67 \% \\
-4.11 \% \\
-2.97 \% \\
0.41 \%\end{array}$ & $\begin{array}{l}-3.66 \% \\
-1.43 \% \\
-2.78 \% \\
0.56 \%\end{array}$ & $\begin{array}{l}-3.83 \% \\
-2.21 \% \\
-2.34 \% \\
0.71 \%\end{array}$ & $\begin{array}{l}-6.02 \% \\
-3.25 \% \\
-3.41 \% \\
0.64 \%\end{array}$ & $\begin{array}{l}-4.46 \% \\
-1.97 \% \\
-2.75 \% \\
0.25 \%\end{array}$ & $\begin{array}{l}-4.55 \% \\
-2.81 \% \\
-2.91 \% \\
1.17 \%\end{array}$ \\
\hline Income Shock & 1.0195 & 1.0188 & 1.0189 & 1.0191 & 1.0192 & 1.0189 \\
\hline
\end{tabular}

Note: Leverage Ratio is the long-term debt value $L$ divided by Firm Value; Investment Ratio, investment $I$ divided by capital stock $K$; and Firm Value, the sum of equity $V$ and debt $L$ values. Value from Operations is the expected discounted value of the firm's investment and production activities; Tax Benefit is the expected discounted value of the interest payment deduction; Default Cost is the expected discounted value of the deadweight default cost $X$. The Difference in Firm Values is measured by the difference in firm values $V+L$ between the equity-value-maximizing firm and the total-value-maximizing firm over the total-value-maximizing firm value. When the capital structure can respond to parameter changes, results with long-term debt in this table and with short-term debt in the next table are qualitatively similar. Instead, a more informative experiment is performed. The long-term debt coupon is held at its optimal ex ante level of 0.03 for the equityvalue-maximizing firm and 0.055 for the total-value-maximizing firm. 
Table 4: Overhang with Short-term Debt for Different Calibrations

\begin{tabular}{|c|cccccc|}
\hline & $\delta=0.135$ & $\delta=0.145$ & $\rho=0.58$ & $\rho=0.62$ & $\sigma=0.13$ & $\sigma=0.15$ \\
& & & & & & \\
\hline & $54.27 \%$ & $49.40 \%$ & $54.88 \%$ & $48.24 \%$ & $55.74 \%$ & $47.55 \%$ \\
Leverage Ratio & $(0.0978)$ & $(0.1092)$ & $(0.0957)$ & $(0.1135)$ & $(0.0937)$ & $(0.1146)$ \\
$S /(V+S)$ & & & & & & \\
& $14.49 \%$ & $15.49 \%$ & $14.96 \%$ & $15.04 \%$ & $14.88 \%$ & $15.12 \%$ \\
Investment Ratio & $(0.1386)$ & $(0.1386)$ & $(0.1360)$ & $(0.1412)$ & $(0.1297)$ & $(0.1477)$ \\
$I / K$ & & & & & & \\
& 2.2141 & 1.9253 & 2.1537 & 1.9630 & 2.1742 & 1.9484 \\
Firm Value & $(0.4431)$ & $(0.4515)$ & $(0.4362)$ & $(0.4809)$ & $(0.4297)$ & $(0.4852)$ \\
$(V+S)$ & & & & & & \\
Percentage from: & $93.80 \%$ & $94.97 \%$ & $94.14 \%$ & $94.68 \%$ & $94.05 \%$ & $94.80 \%$ \\
Value from Operations & $9.15 \%$ & $8.63 \%$ & $9.12 \%$ & $8.63 \%$ & $9.21 \%$ & $8.54 \%$ \\
Tax Benefit & $-2.95 \%$ & $-3.60 \%$ & $-3.26 \%$ & $-3.31 \%$ & $-3.26 \%$ & $-3.34 \%$ \\
Default Cost & & & & & & \\
Difference in: & & & & & & \\
Firm Values & $-5.14 \%$ & $-4.85 \%$ & $-5.20 \%$ & $-5.10 \%$ & $-5.24 \%$ & $-5.10 \%$ \\
Values from Operations & $-4.99 \%$ & $-4.75 \%$ & $-5.07 \%$ & $-4.95 \%$ & $-5.12 \%$ & $-4.94 \%$ \\
Tax Benefits & $-0.65 \%$ & $-0.64 \%$ & $-0.64 \%$ & $-0.70 \%$ & $-0.64 \%$ & $-0.70 \%$ \\
Default Costs & $0.50 \%$ & $0.54 \%$ & $0.51 \%$ & $0.54 \%$ & $0.52 \%$ & $0.54 \%$ \\
Income Shock & 1.0192 & 1.0192 & 1.0243 & 1.0133 & 1.0254 & 1.0126 \\
& & & & & & \\
\hline
\end{tabular}

Note: Leverage Ratio is the short-term debt value $S$ divided by Firm Value; Investment Ratio, investment $I$ divided by capital stock $K$; and Firm Value, the sum of equity $V$ and debt $S$ values. Value from Operations is the expected discounted value of the firm's investment and production activities; Tax Benefit is the expected discounted value of the interest payment deduction; Default Cost is the expected discounted value of the deadweight default cost $X$. The Difference in Firm Values is measured by the difference in firm values $V+S$ between the equity-value-maximizing firm and the total-value-maximizing firm over the total-value-maximizing firm value. 
Table 4: Overhang with Short-term Debt for Different Calibrations (Continued)

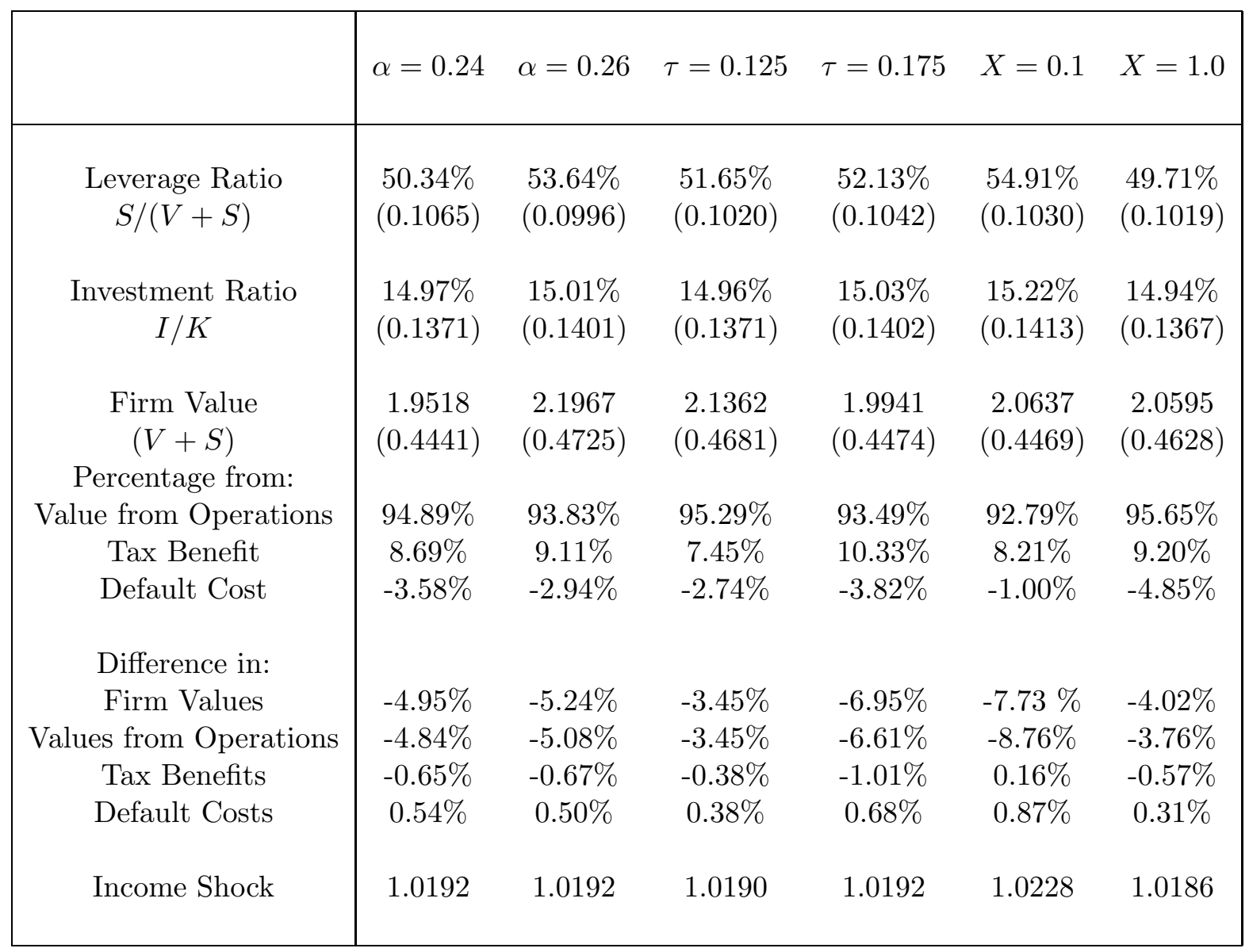

Note: Leverage Ratio is the short-term debt value $S$ divided by Firm Value; Investment Ratio, investment $I$ divided by capital stock $K$; and Firm Value, the sum of equity $V$ and debt $S$ values. Value from Operations is the expected discounted value of the firm's investment and production activities; Tax Benefit is the expected discounted value of the interest payment deduction; Default Cost is the expected discounted value of the deadweight default cost $X$. The Difference in Firm Values is measured by the difference in firm values $V+S$ between the equity-value-maximizing firm and the total-value-maximizing firm over the total-value-maximizing firm value. 
Table 5: Accuracy of Numerical Solution

\begin{tabular}{|c|c|c|c|}
\hline \multirow[b]{2}{*}{ Sample Size $T$} & \multirow{2}{*}{$\begin{array}{c}\text { Max Absolute Residual } \\
\text { within } 95 \% \text { of observations }\end{array}$} & \multicolumn{2}{|c|}{ Den Haan-Marcet Test Values } \\
\hline & & Lower $2.5 \%$ & Higher $2.5 \%$ \\
\hline \multicolumn{4}{|c|}{ Total-value-maximizing Firm with Long-term Debt: } \\
\hline 100 & $6.0059 \times 10^{-6}$ & $1.40 \%$ & $13.00 \%$ \\
\hline 500 & $5.2497 \times 10^{-6}$ & $0.20 \%$ & $2.40 \%$ \\
\hline 1000 & $5.0657 \times 10^{-6}$ & $0.00 \%$ & $5.60 \%$ \\
\hline \multicolumn{4}{|c|}{ Equity-value-maximizing Firm with Long-term Debt: } \\
\hline 100 & $8.9619 \times 10^{-6}$ & $2.80 \%$ & $20.20 \%$ \\
\hline 500 & $8.3451 \times 10^{-6}$ & $3.40 \%$ & $4.60 \%$ \\
\hline 1000 & $8.3437 \times 10^{-6}$ & $2.00 \%$ & $3.20 \%$ \\
\hline \multicolumn{4}{|c|}{ Total-value-maximizing Firm with Short-term Debt: } \\
\hline 100 & $1.9773 \times 10^{-5}$ & $5.00 \%$ & $21.40 \%$ \\
\hline 500 & $1.9692 \times 10^{-5}$ & $3.20 \%$ & $4.00 \%$ \\
\hline 1000 & $1.9593 \times 10^{-5}$ & $2.00 \%$ & $4.20 \%$ \\
\hline \multicolumn{4}{|c|}{ Equity-value-maximizing Firm with Short-term Debt: } \\
\hline 100 & $2.4054 \times 10^{-5}$ & $4.20 \%$ & $4.20 \%$ \\
\hline 500 & $2.3716 \times 10^{-5}$ & $2.00 \%$ & $2.00 \%$ \\
\hline 1000 & $2.3589 \times 10^{-5}$ & $2.20 \%$ & $4.00 \%$ \\
\hline
\end{tabular}

Note: The Accuracy Test is taken from Den Haan and Marcet (1994). The test is computed from the Euler residuals of 500 different time series, using the consistent covariance estimator of Newey and West (1987). The accuracy test results are not sensitive to the choice of instruments variables, which consist of the constant and state variables. 


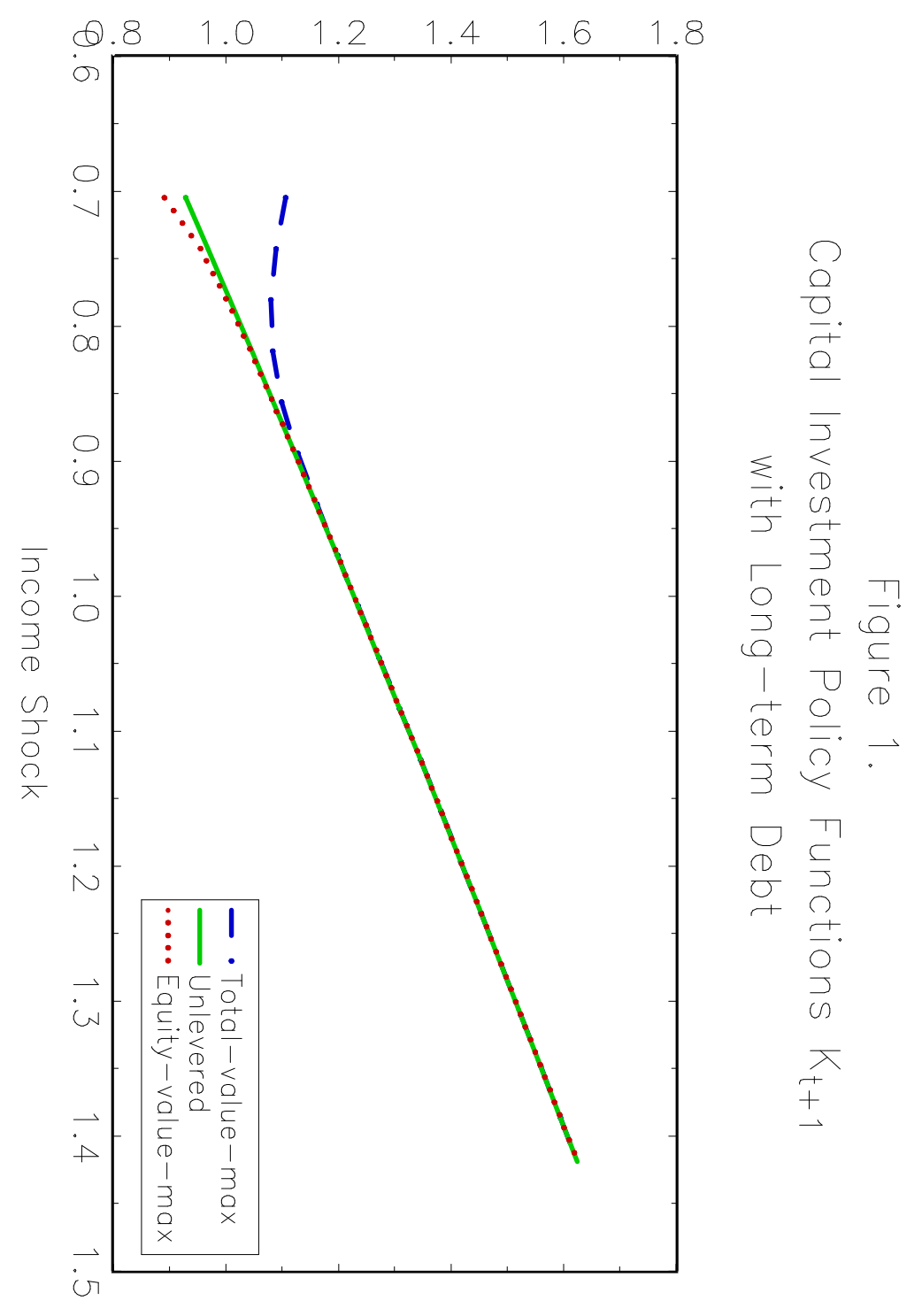




$$
\nabla
$$


D. 